\title{
التعلق النصي لألف ليلة وليلة، مرجعا للحقيقة والوهم،في جملكية آرابيا لواسيني الأعرج
}

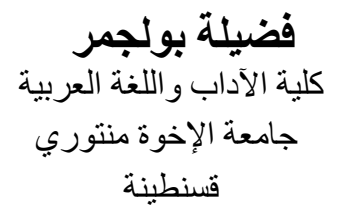

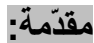

عرفت الرواية تطور ات مختلفة؛ الغربية منها

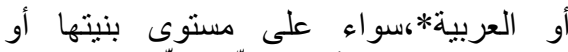

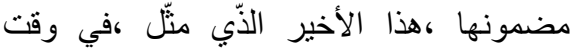

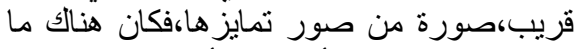

يسمى رو اية واقعية أو نفسية أواجتماعية **....

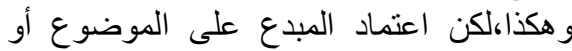

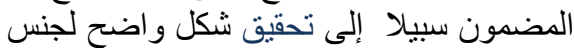

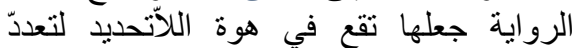

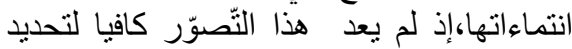

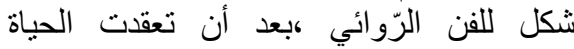

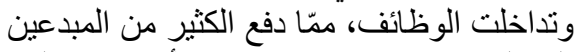

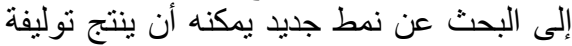

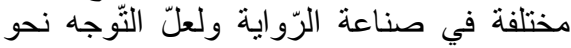

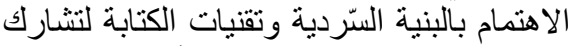

المضمون في إنتاج فنّ الرّو اية أسهم في تحديد الإنيد

إطارها الأجناسي وشكلها لتكون في الأخير التياجي

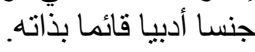

تجبه الرو اية العربية اللى البحث عن شكل رو ائي قادر على التعبير

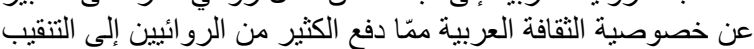

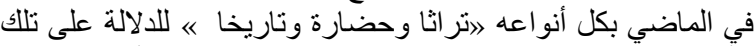

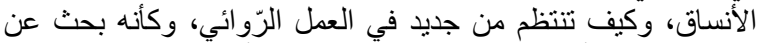

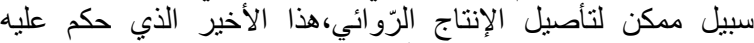

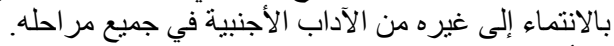

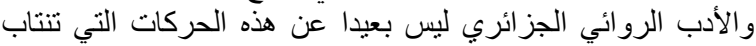

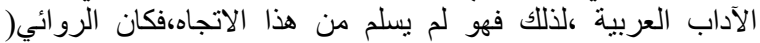

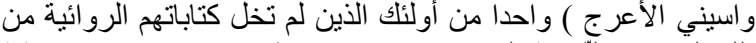

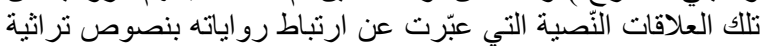

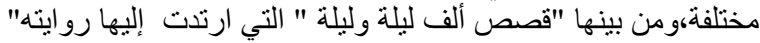

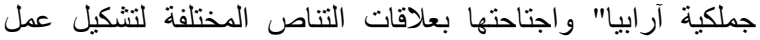

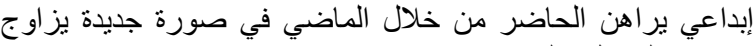
فيها بين التخييل و الو اقع.

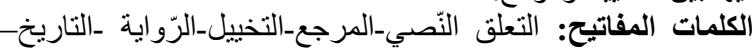
العالم الواقعي ـالنص السابق ـالنص النص النصق

\begin{abstract}
:
The Arabic fiction, while trying to be innovative, is looking for literary forms capable of displaying the characteristics and merits of the Arab culture. Therefore, a lot of novelists try not only to delve into the Arabic heritage, culture and history to find about these novelistic formats and modes but also to figure out how to re-organize and use them in new fictional works. This search can be considered as an attempt to set origins for the Arabic novel, especially that the latter is said to belong to the foreign literature as it was so influenced by it throughout history.

The Algerian fiction is no exception. A good example of this outlook is the Algerian novelist WacinyLaredj. His works are full of sections which clearly reflect a link to different ancient heritable books. They show how much Laredj is under the influence of historic texts such as the stories of "One thousand and One nights", to which his novel "Joumloukia Arabia" has been closely related. This book is filled with salient instances of intertextuality that refer to "One thousand and One nights". In fact, such a work mirrors the writer's creativity in connecting the present with the past and combining imagination with realitv in a new fashion.
\end{abstract}

(C) جامعة الإخوة منتوري قسنطينة،الجزائر2018 


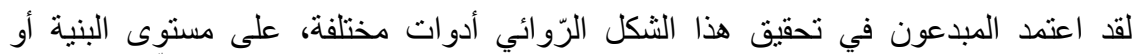

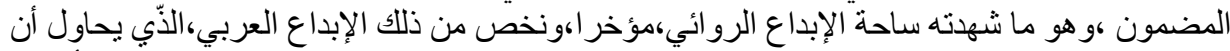

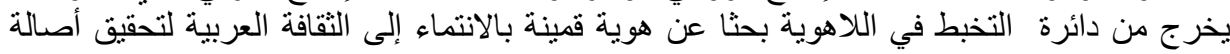

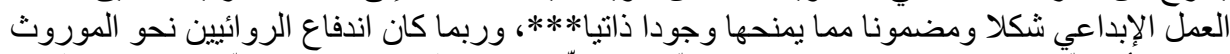

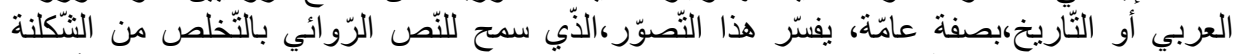

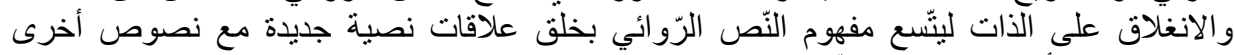

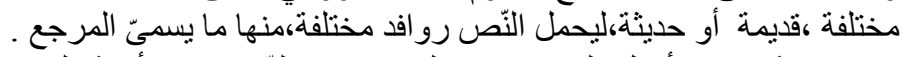

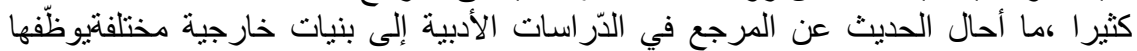

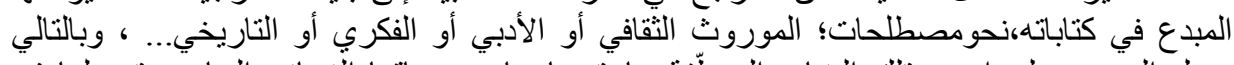

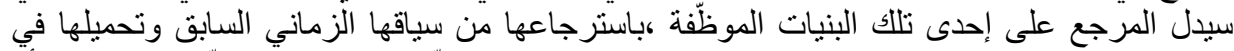

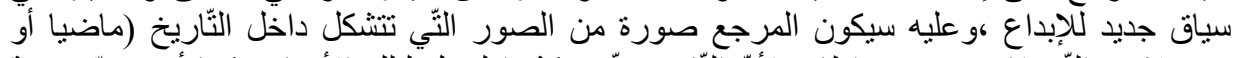

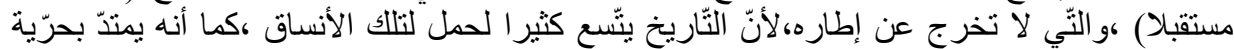

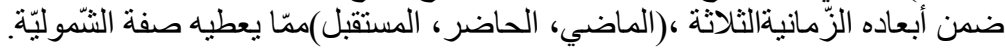

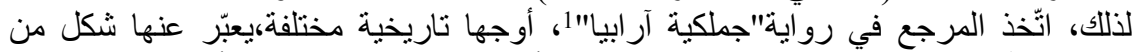

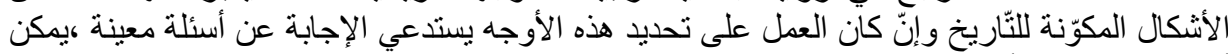

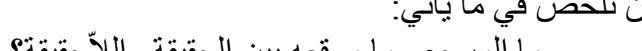

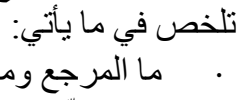

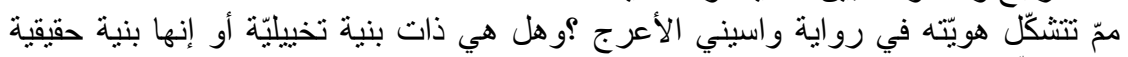
كاف اللو التّاريخي؟

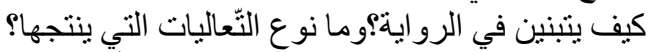

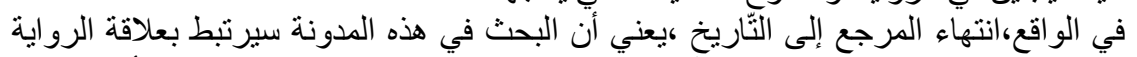

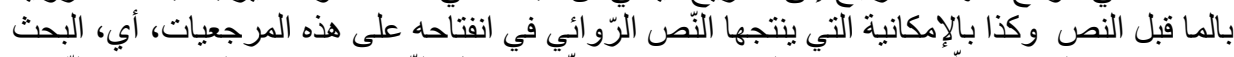

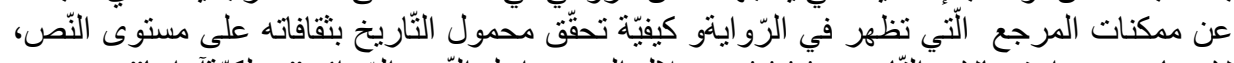

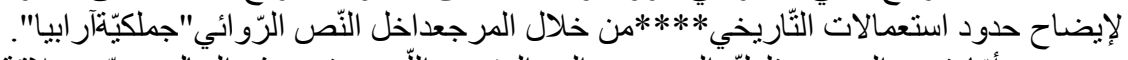

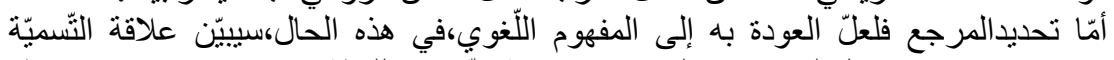

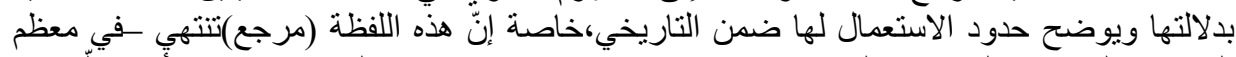

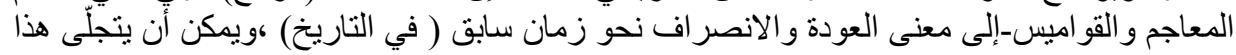

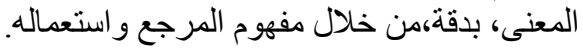
- - - مفهوم المرجع:(اللقطظ والاستعمال)

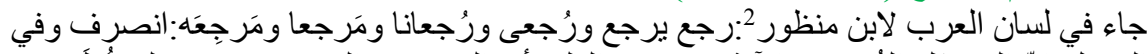

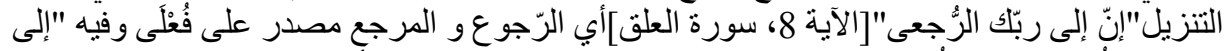

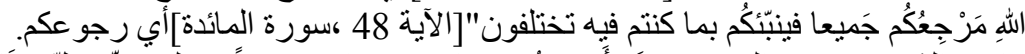

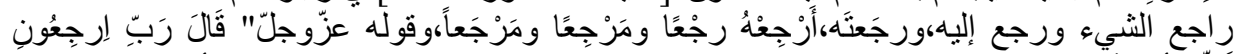

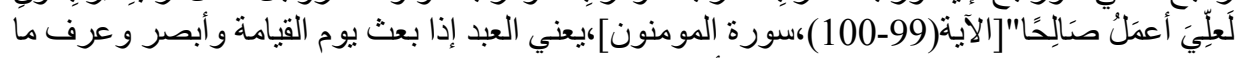

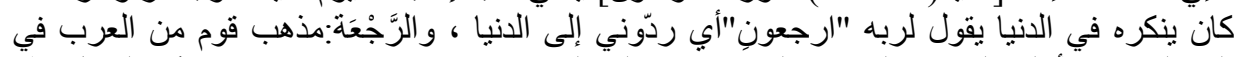

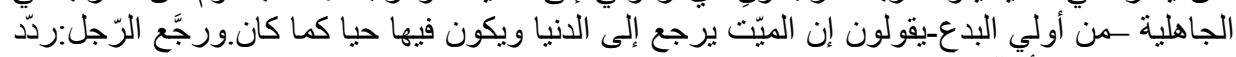

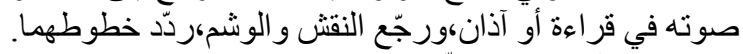

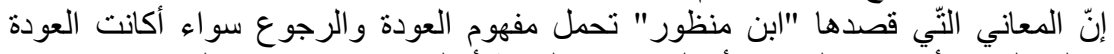

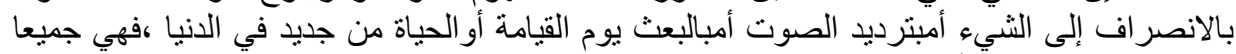
توحي بالانقطاع عن الأمر ثم العودة لاستد المائه من جديد. 


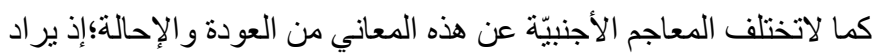

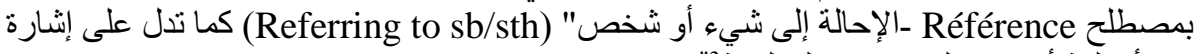

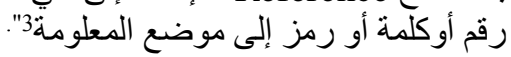

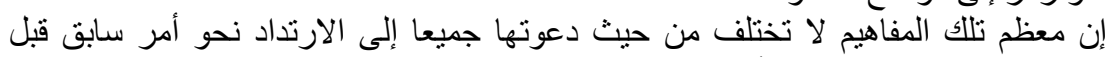

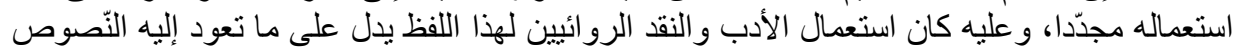

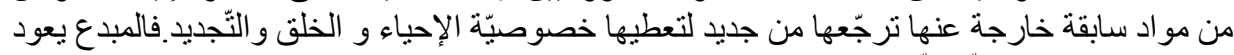

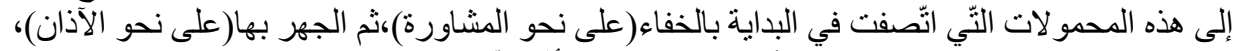

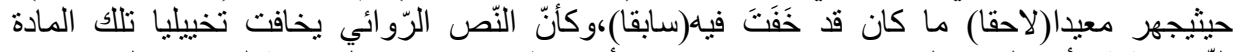

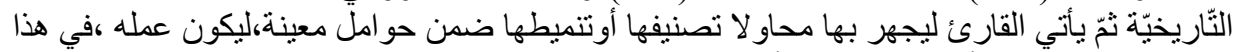
الوضع،شبيهابمن بعدّ أور اق ملكيتها الأصليّة.

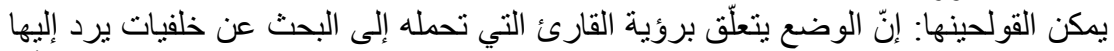

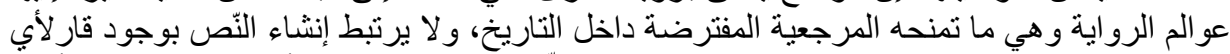

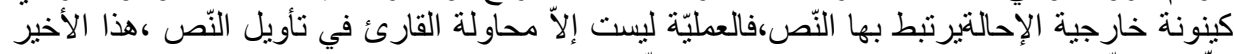

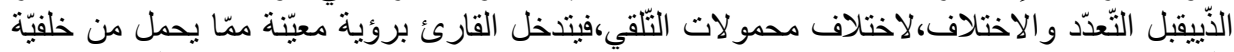

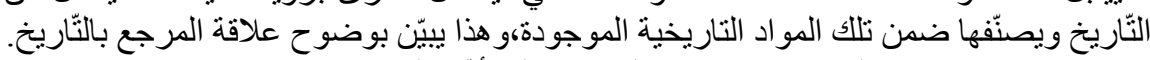

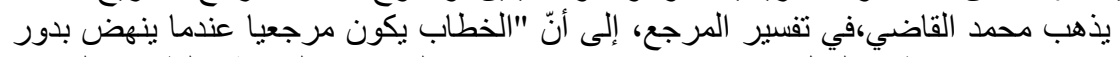

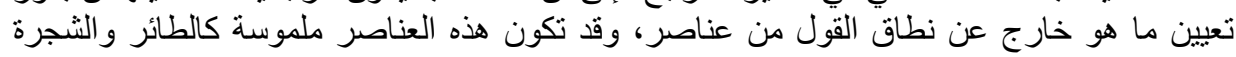

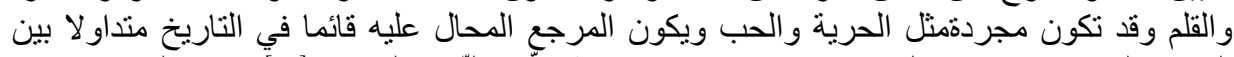

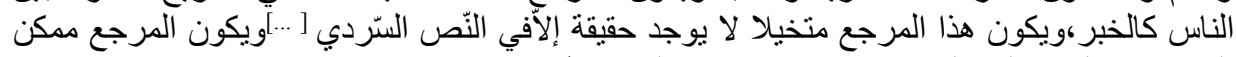

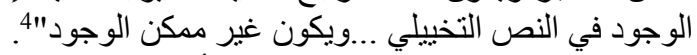

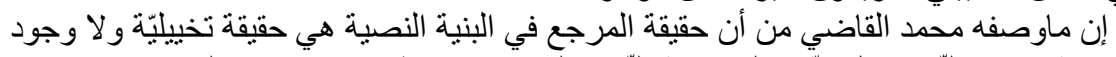

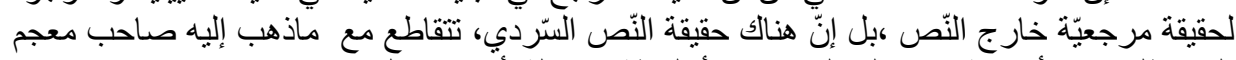

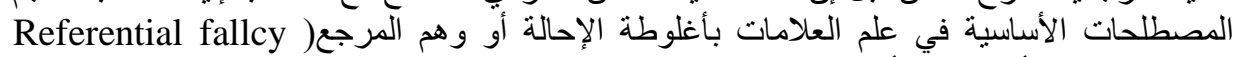

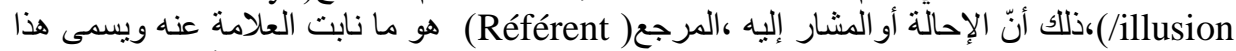

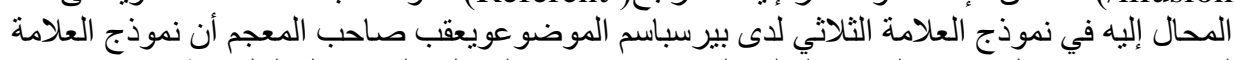

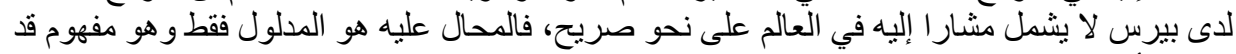

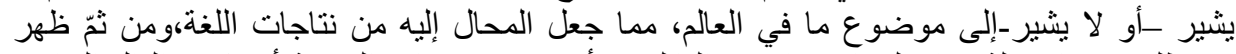

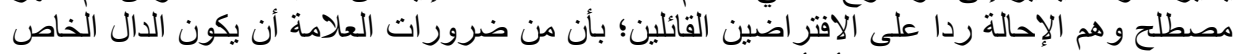

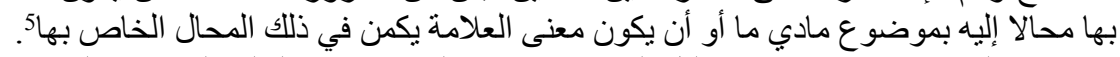

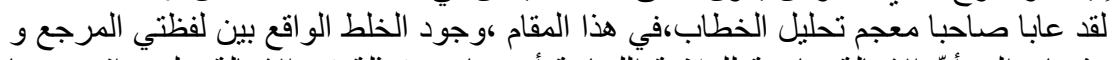

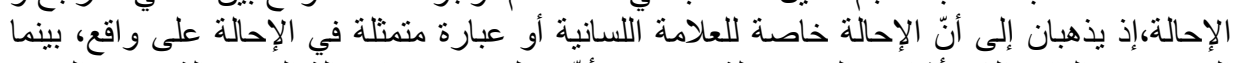

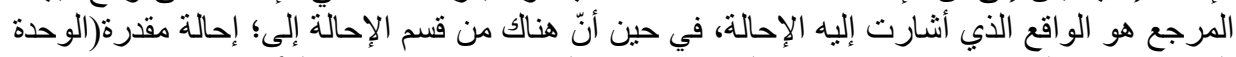

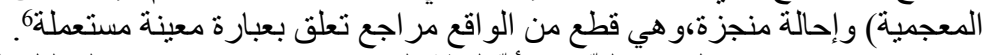

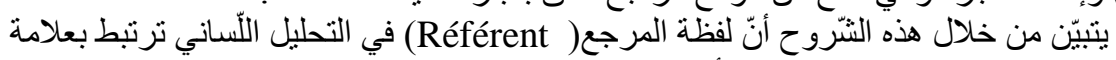

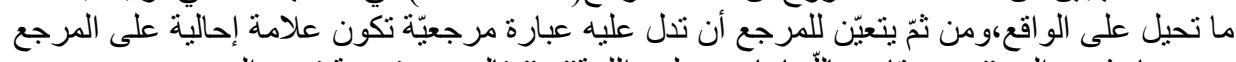

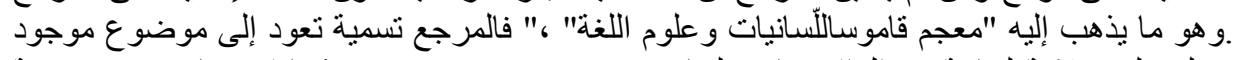

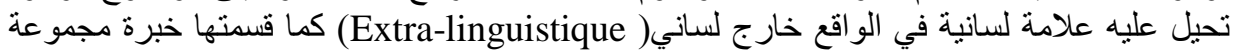

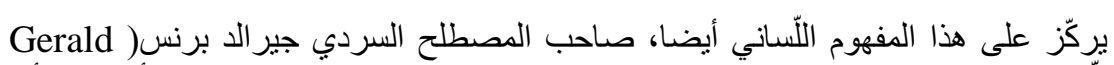
إنسانية" النيل

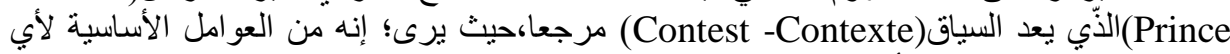

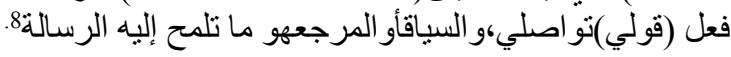




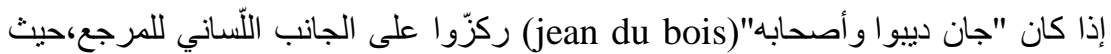

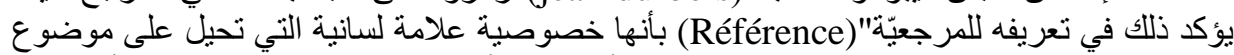

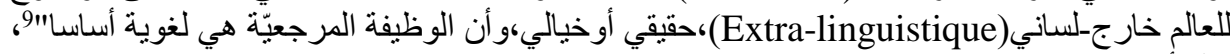

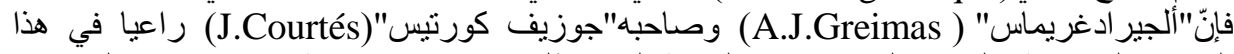

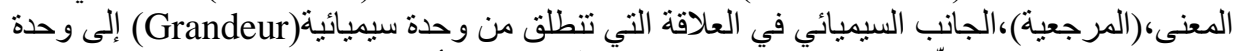

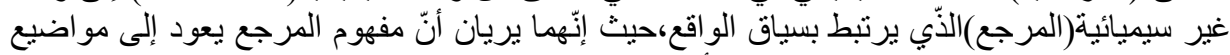

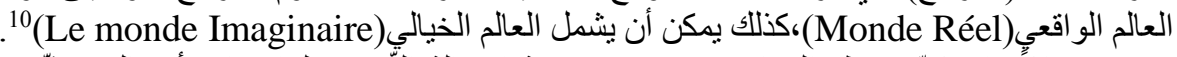

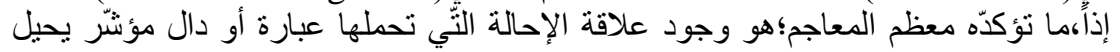

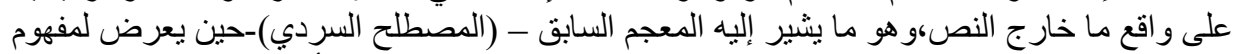

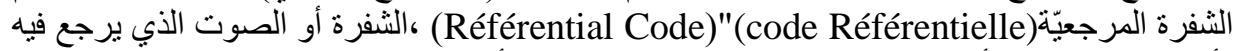

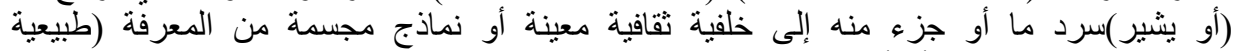

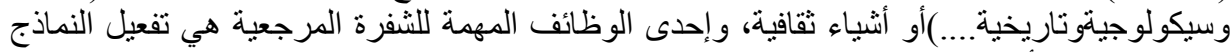

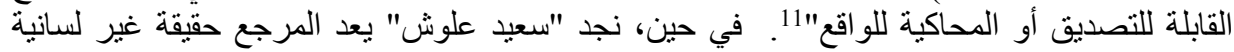

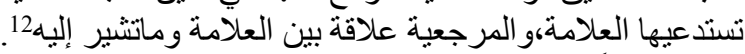

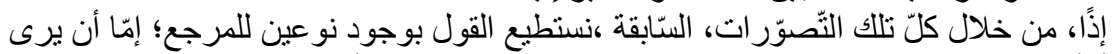

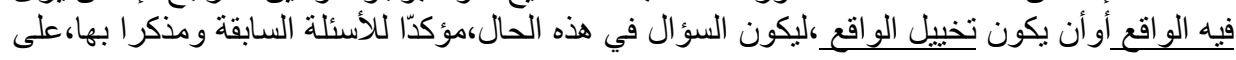

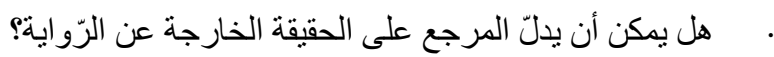
نحو ؛

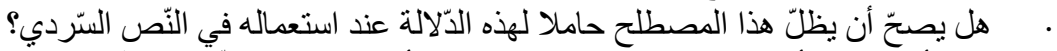

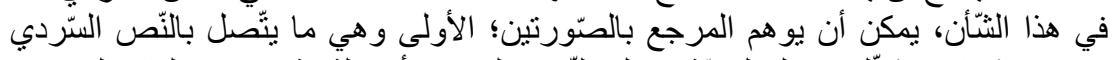

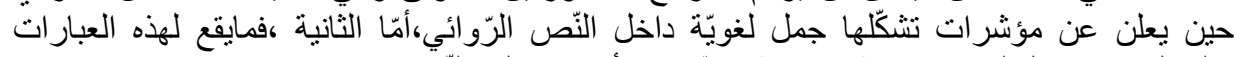

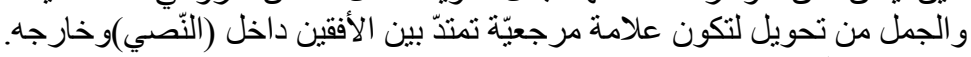

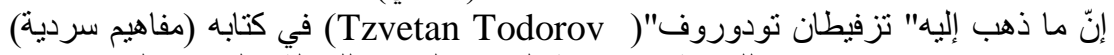

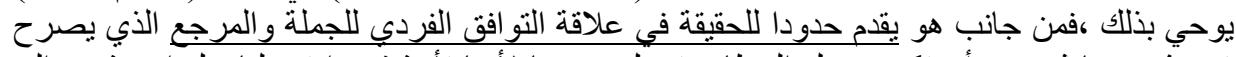

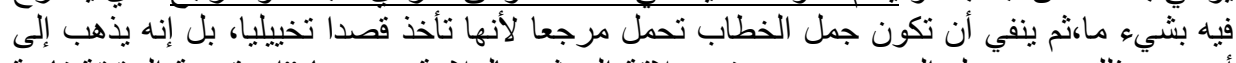

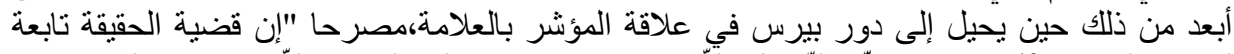

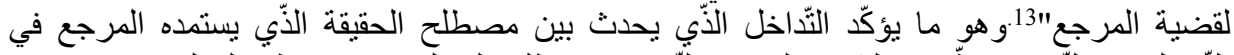

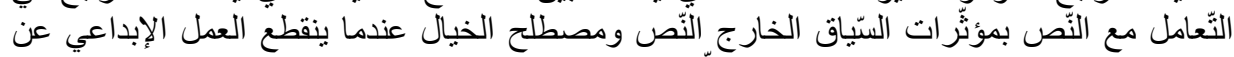
الماخارج النص ويستمد سلطته من الحقيقة اللّنّانيّة.

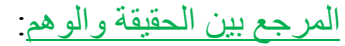

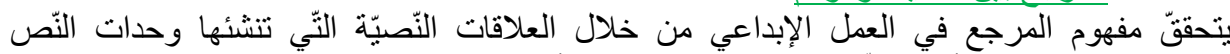

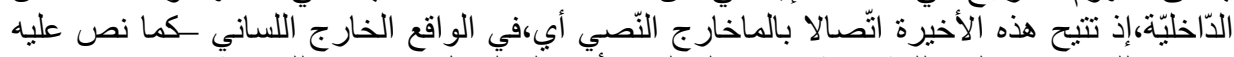

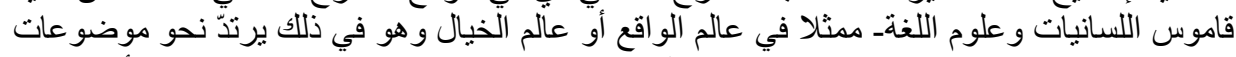

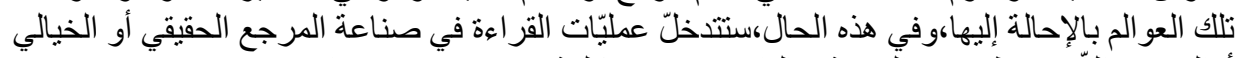

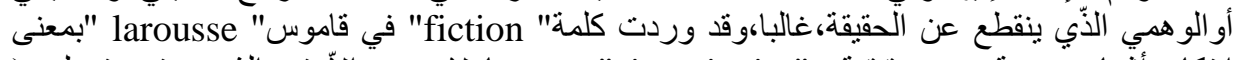

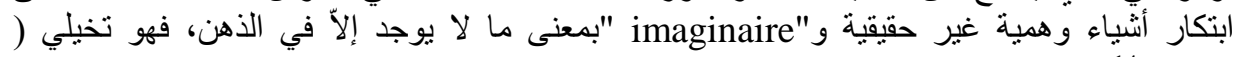

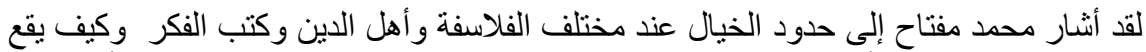

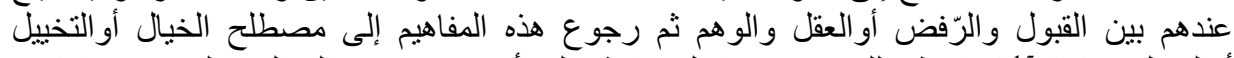

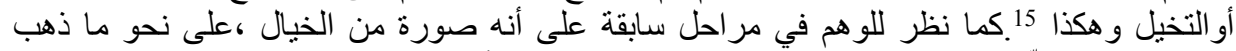

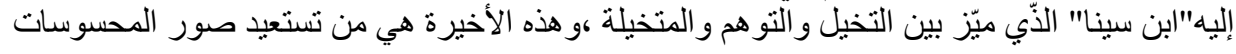


بعد زو الها مباشرة من الحس بالإضافة إلى إعادة تركيبها على نحو جديدو هذه القوة إذا استعملها العقل

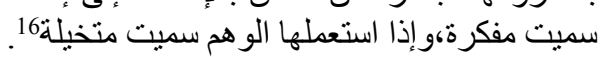

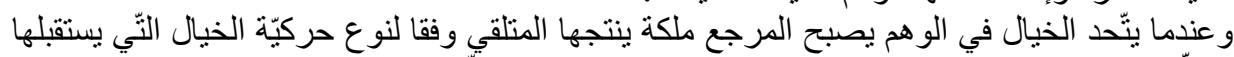

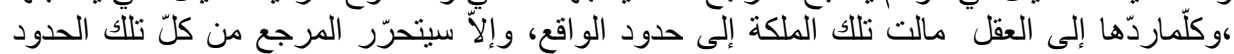

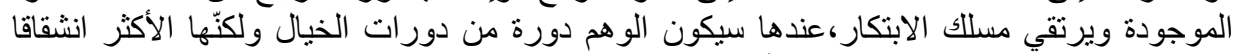

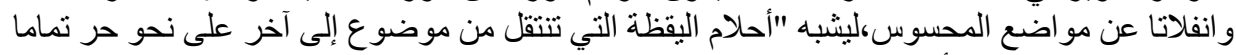

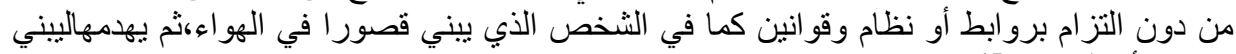

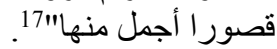

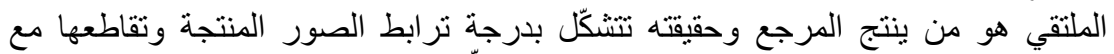

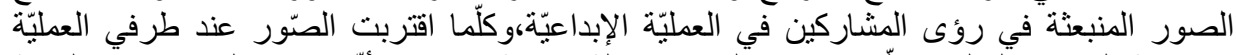

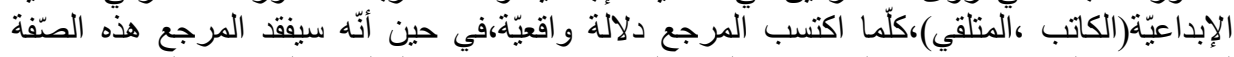

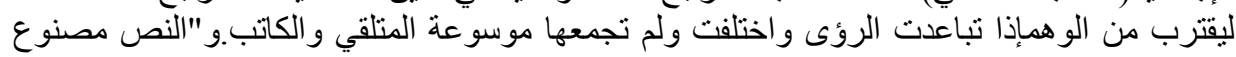

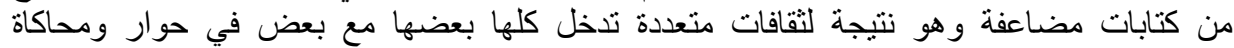

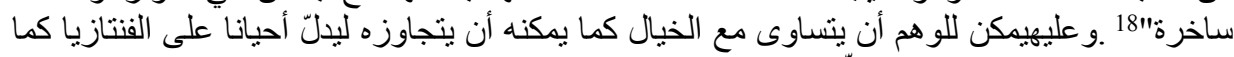

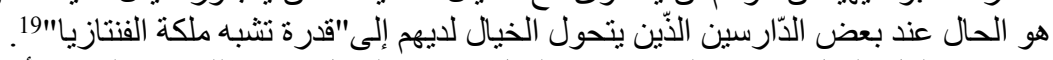

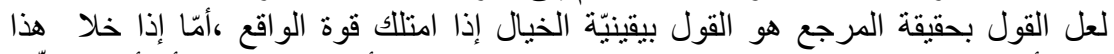

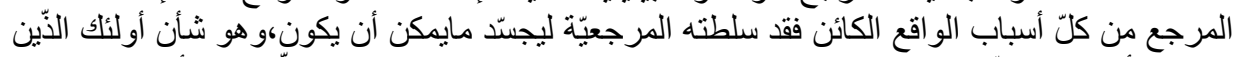

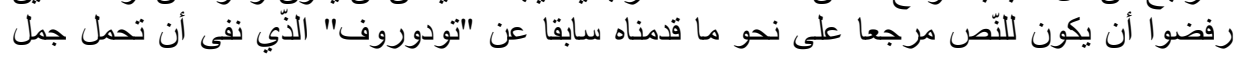

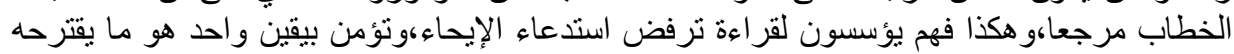

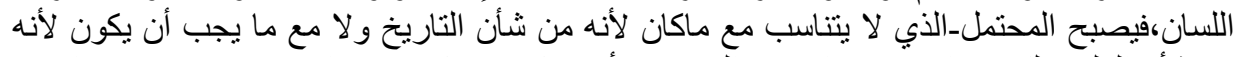

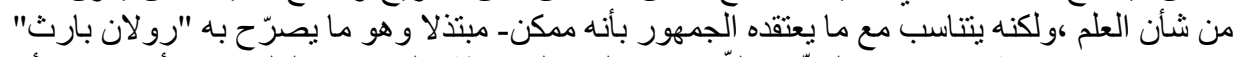

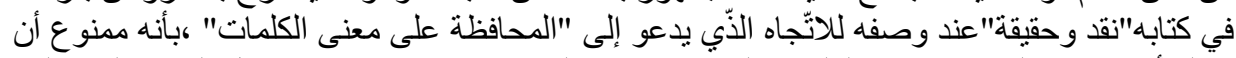

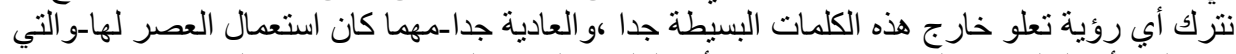

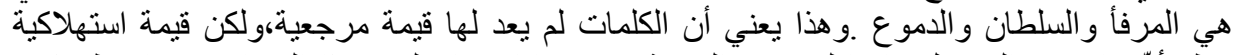

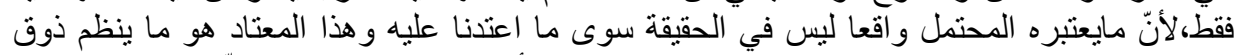

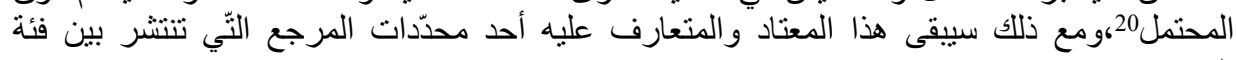

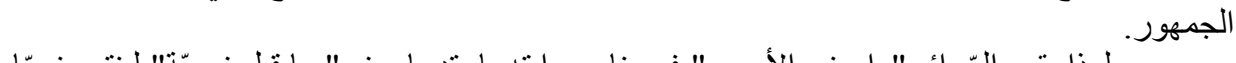

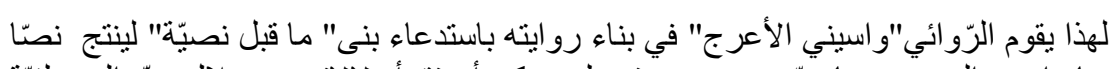

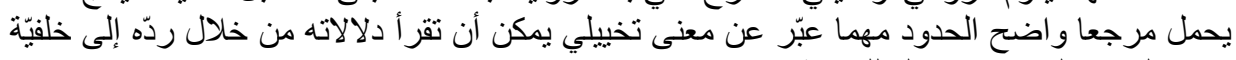

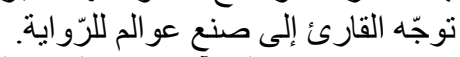

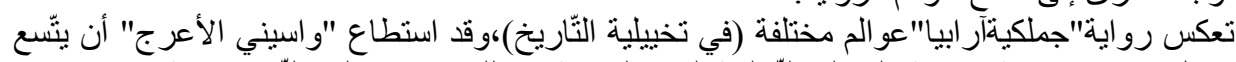

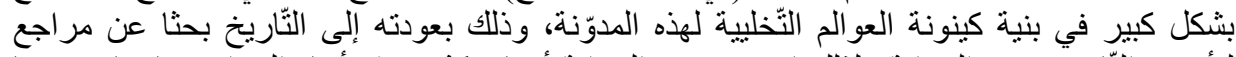

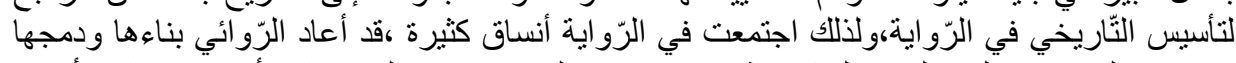

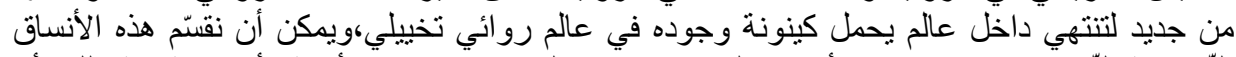

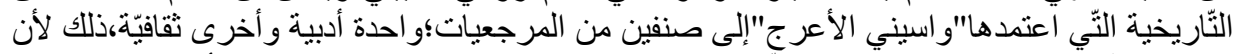

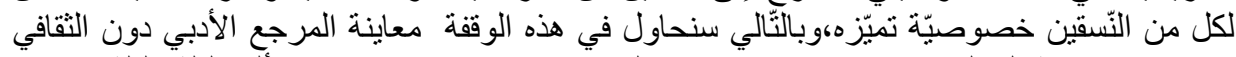

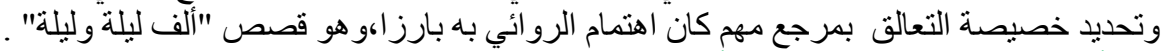

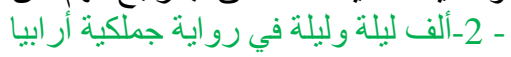

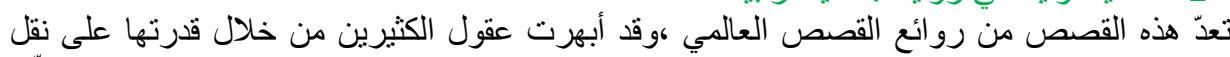

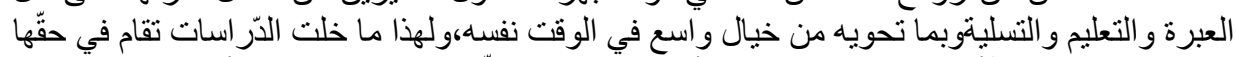

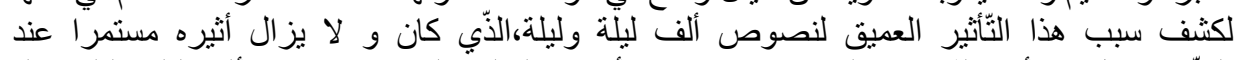
الكتّاب،يقول فيه أحد الذّارسين"لم يشتهر كتاب في أُرجاء العالم مثلما اشتهر كتاب لألف ألف ليلة وليلة...ولم 
يؤثر كتاب -شكلا ومضموناففي الأدب الإنساني مثلما أثر وبشكل واسع و عميق هذا الكتاب،ولم بسهر

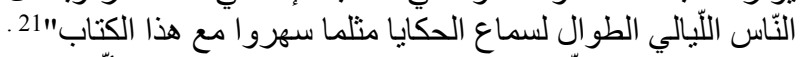

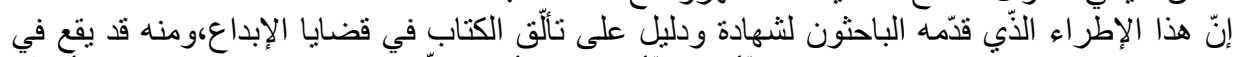

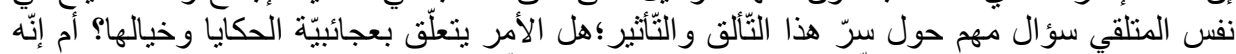

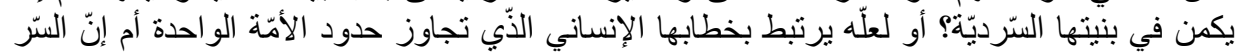

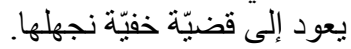

لقد كان لارنباط كثير من المبدعين بهذا المصدر الملهم يجيب عن بعض تلإنك الأسئلة ،"إذ أصبحت

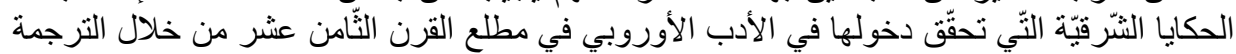

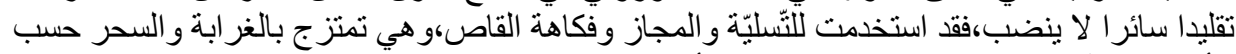

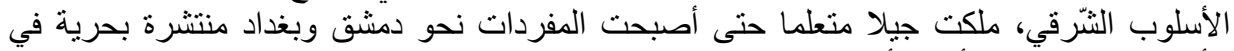

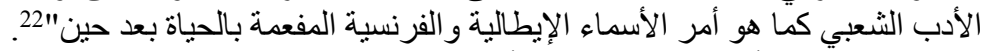

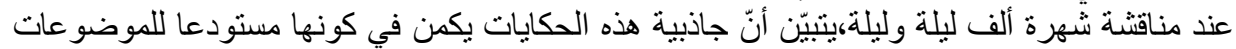

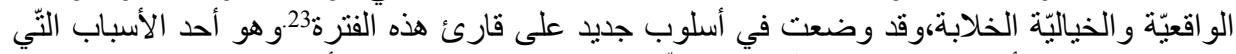

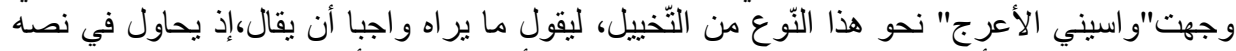

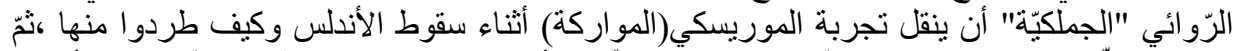

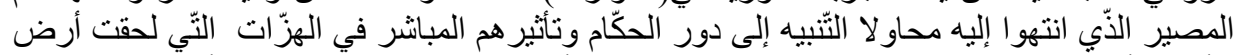

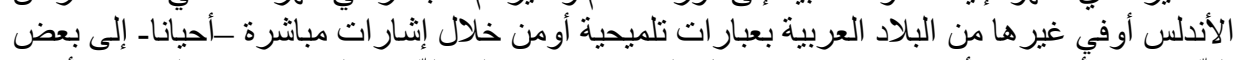

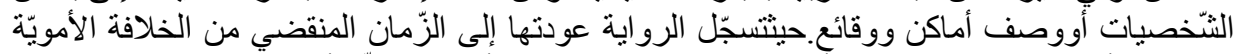

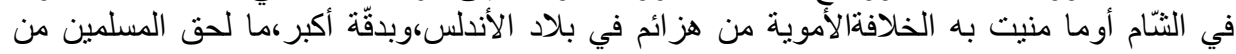
تعذيب في محاكم التفنيش.

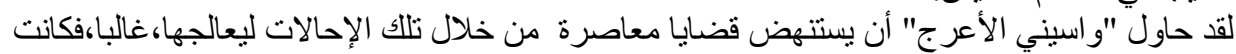

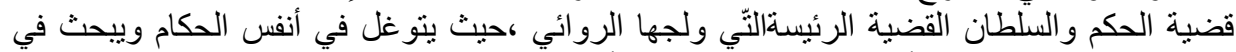

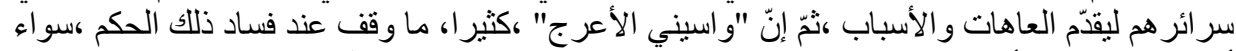

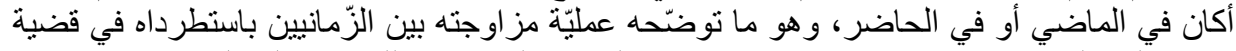

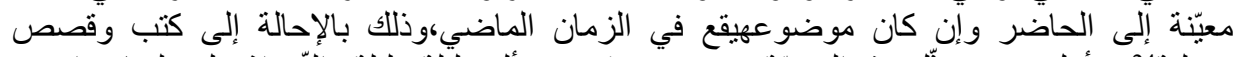

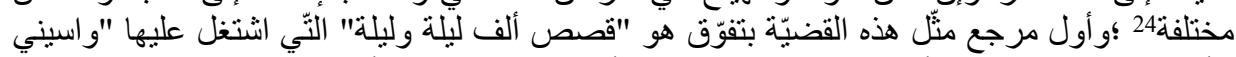

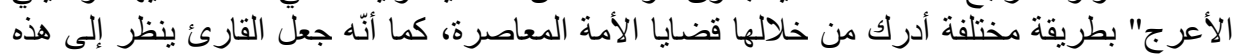

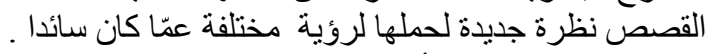

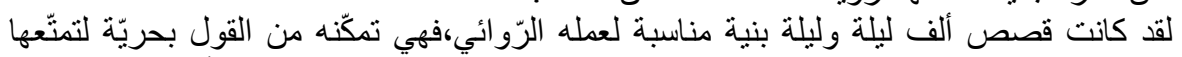

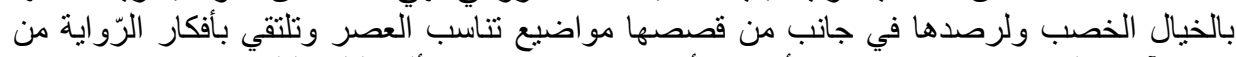

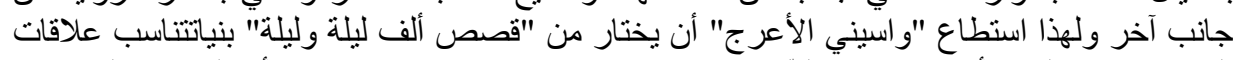

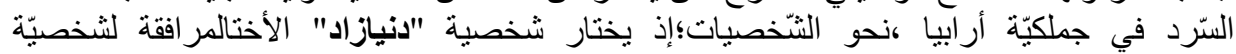

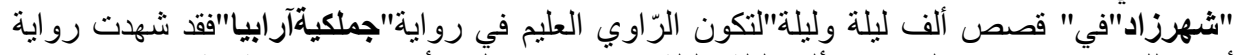

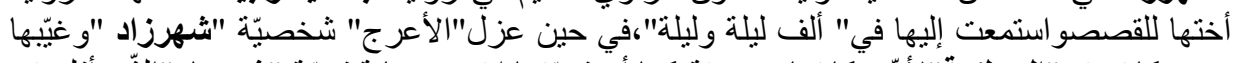

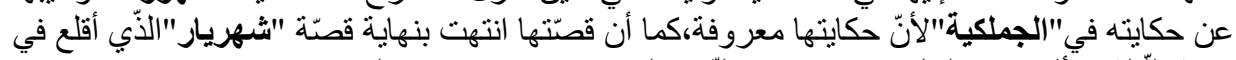

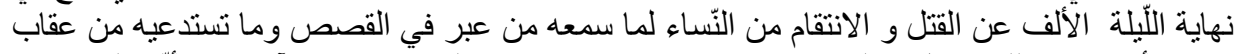

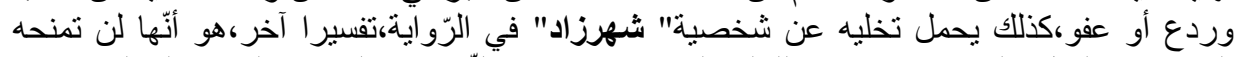

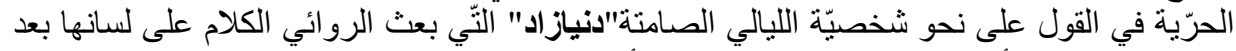

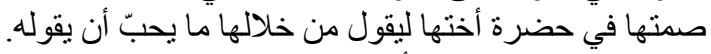

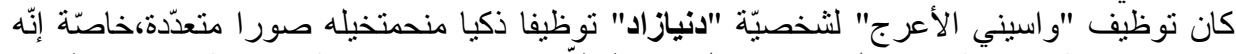

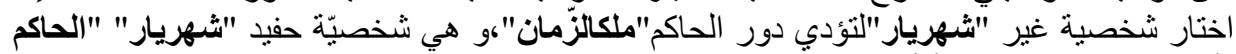

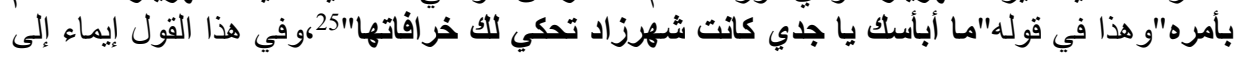




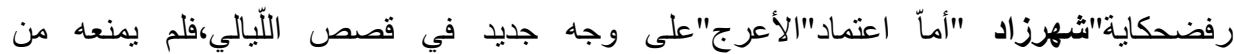

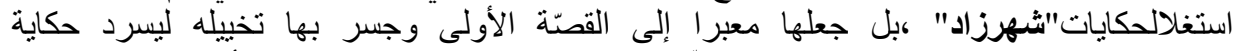

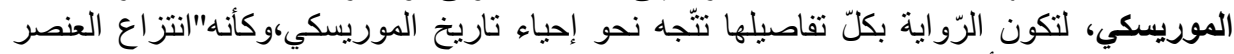

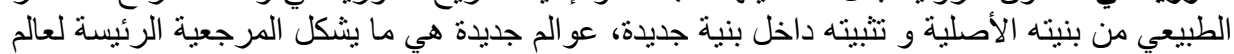

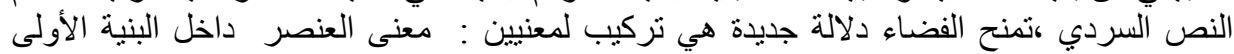

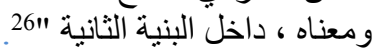

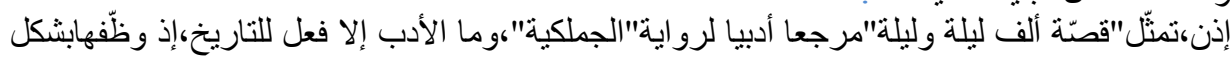

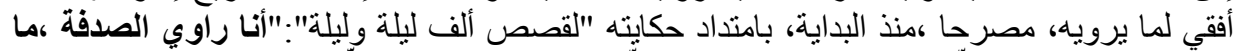

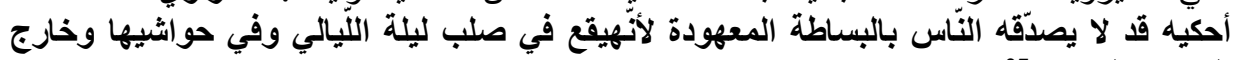

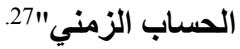

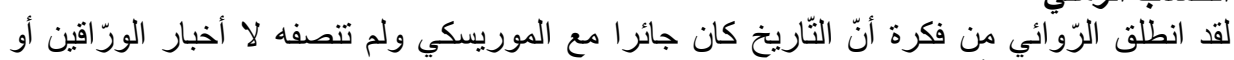

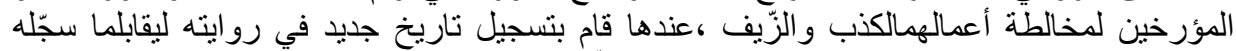

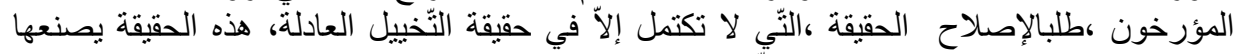

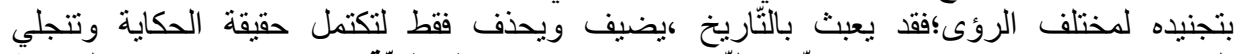

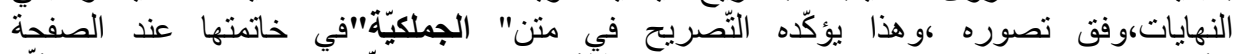

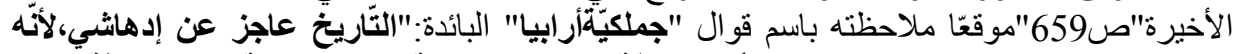

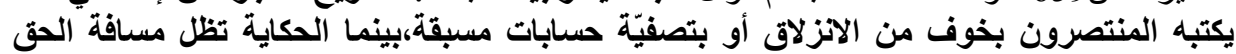

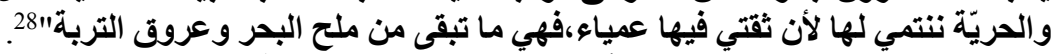

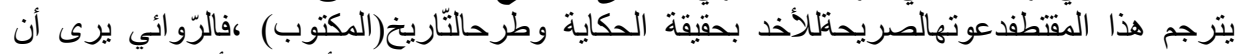

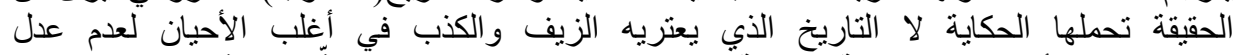

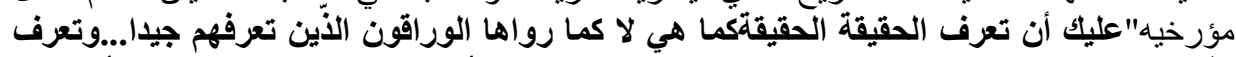

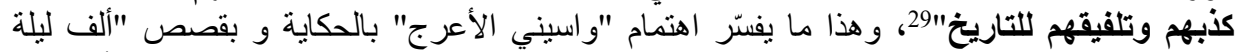

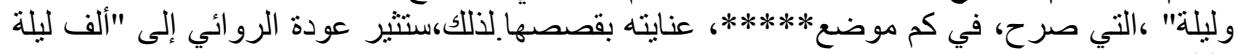

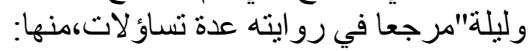

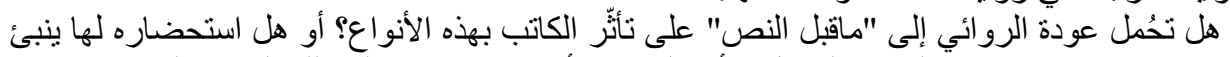

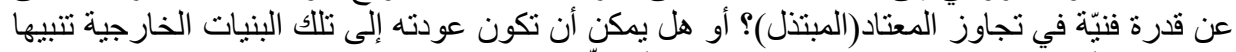

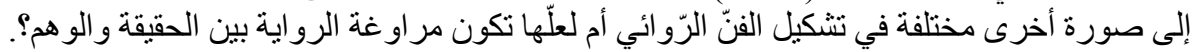

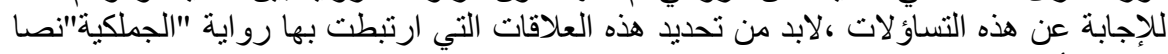

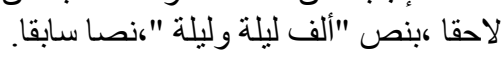

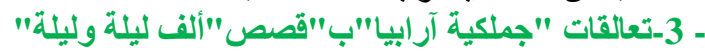

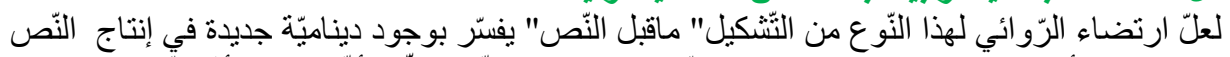

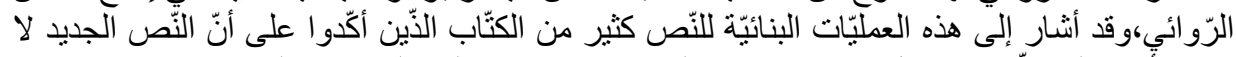

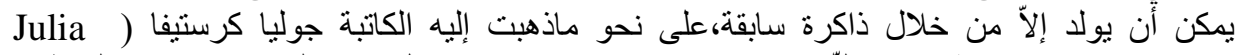
Kristeva

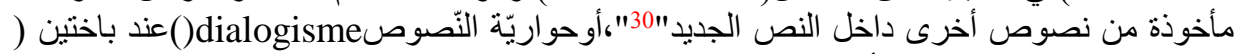

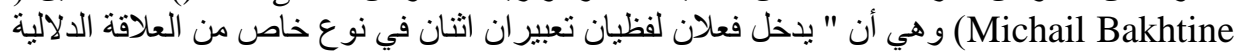

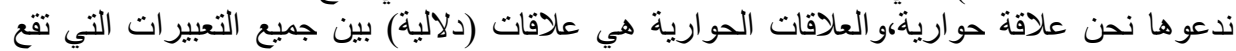

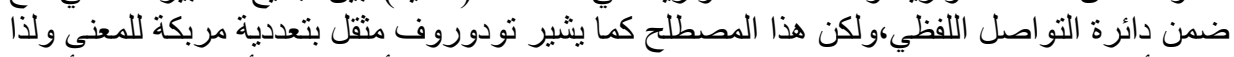

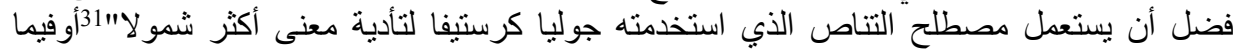

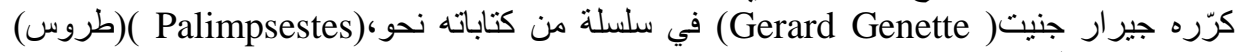

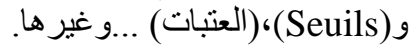


تبرز في نصّ"جملكيةآرابيا" علاقات مهمة أثناء استرجاع الروائي للتاريخ،في بنية جديدة مختلفة،حيث

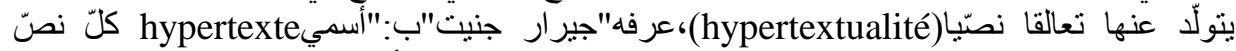

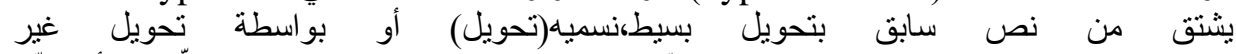

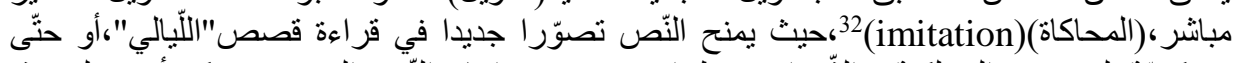

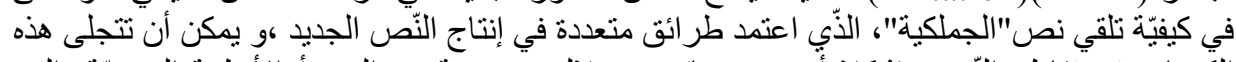

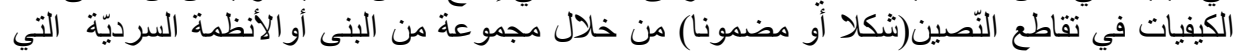

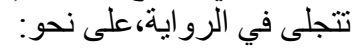

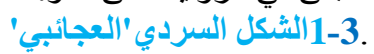

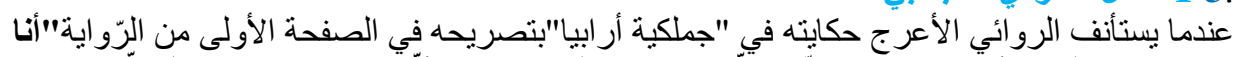

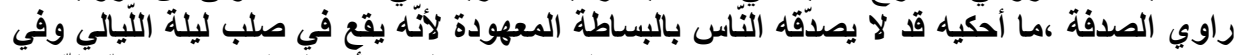

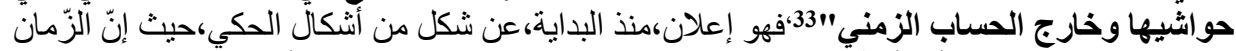

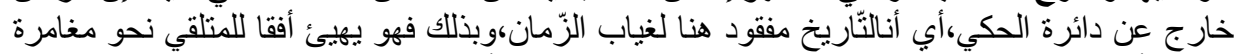

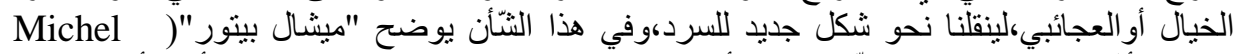

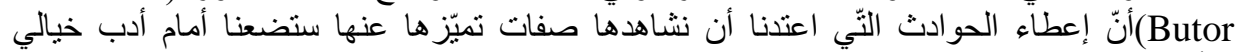

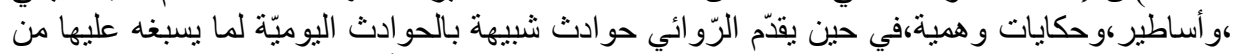

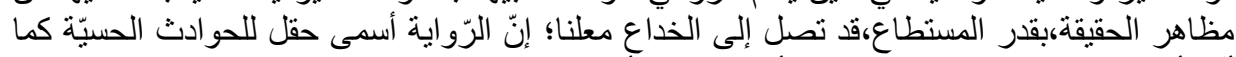

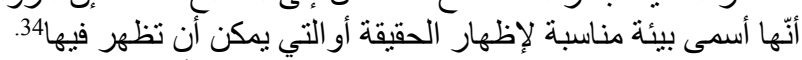

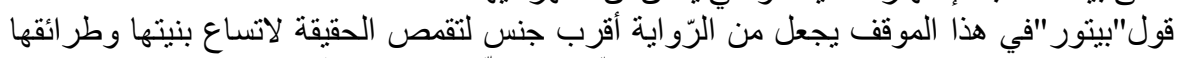

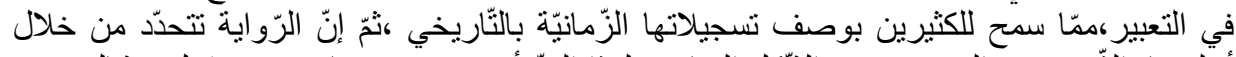

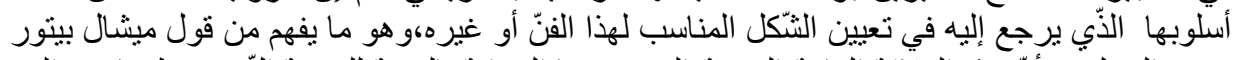

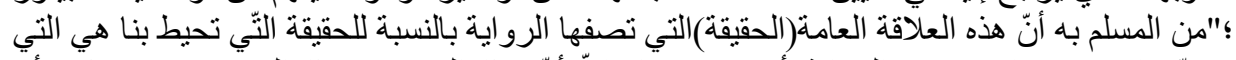

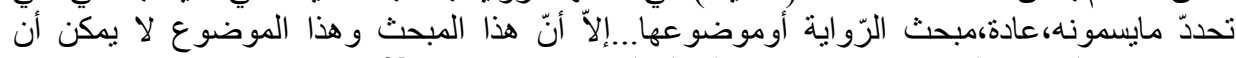

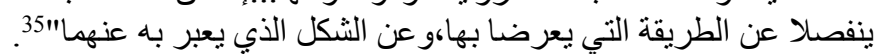

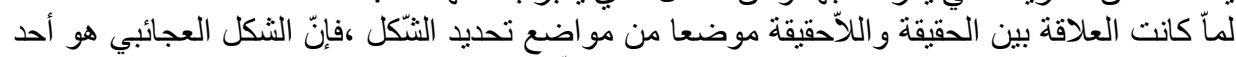

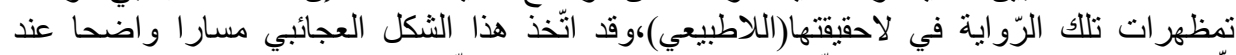

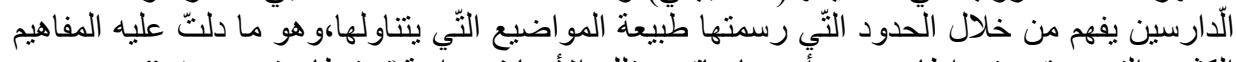

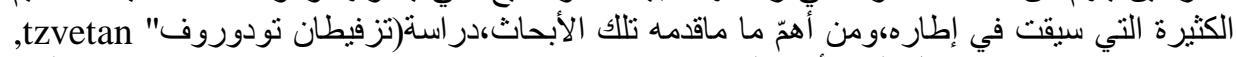
"todorov

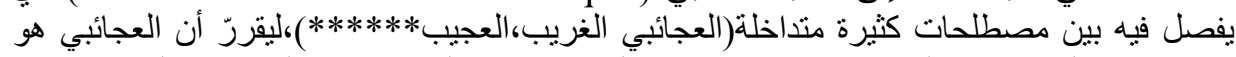

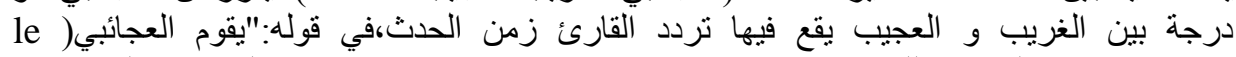
(fantastique

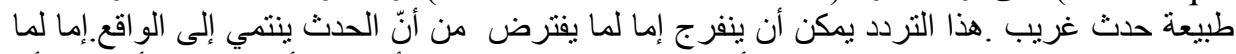

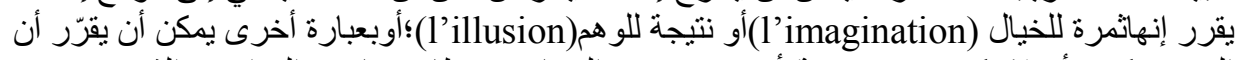

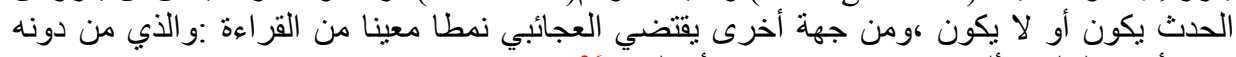

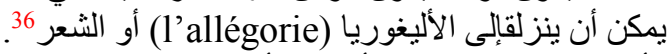

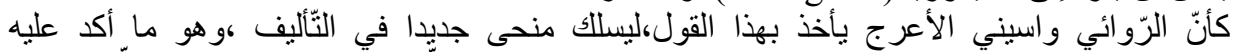

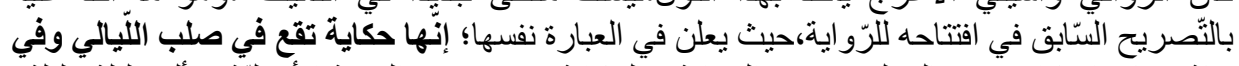

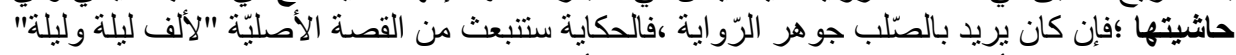

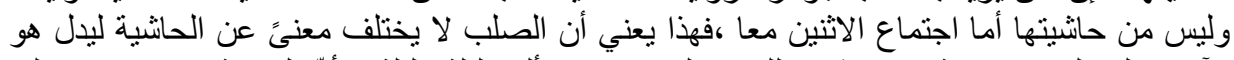

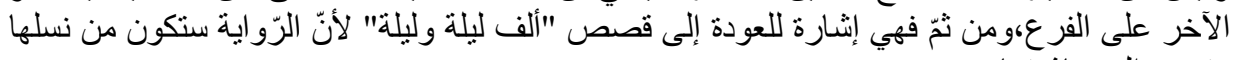


إذًا ،الاستفتاحية تعلن عن وجود مرجع لرّو اية"جملكية أرابيا" ،لكنه ينفي أن تعود إلى تأريخ ما، لأنه

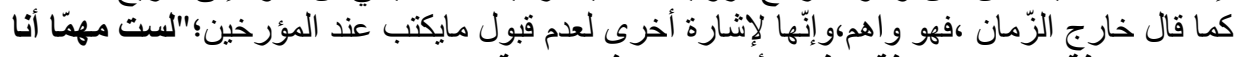

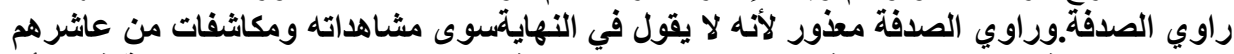

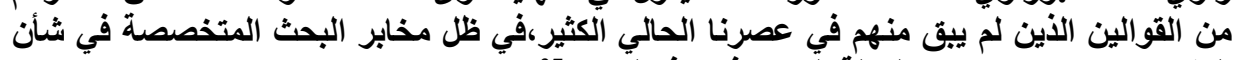

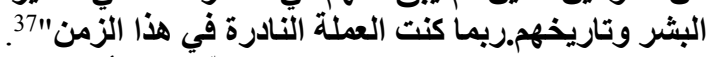

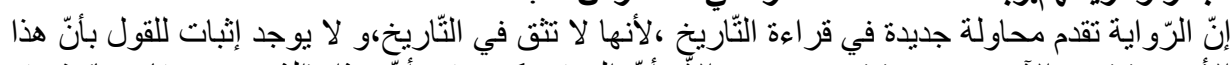

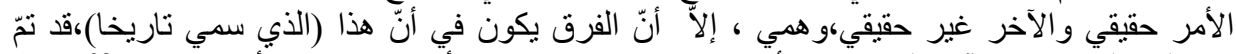

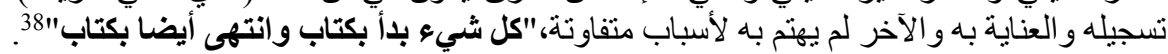

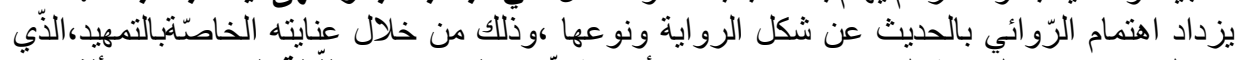

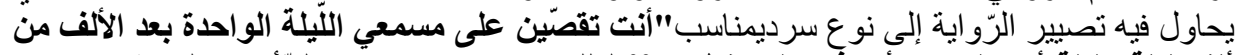

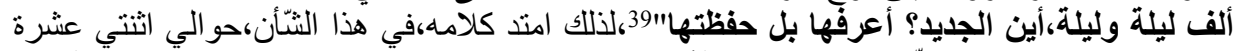

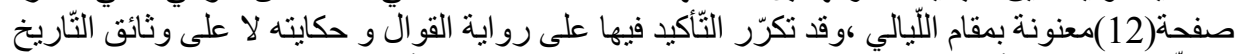

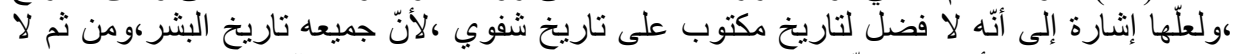

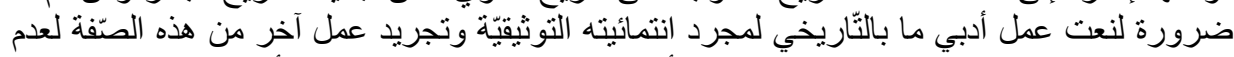

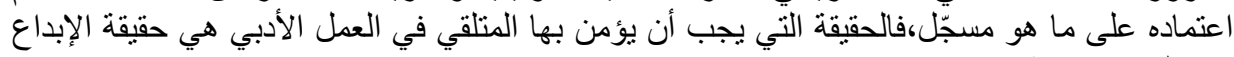
وجماليته لا حقيقة انتمائه.

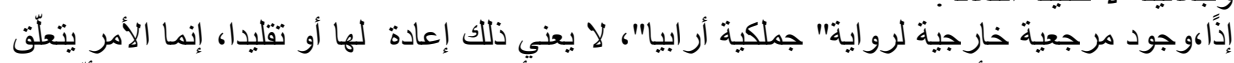

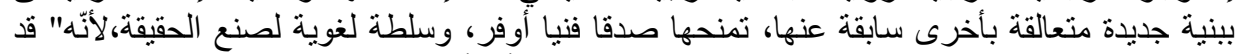

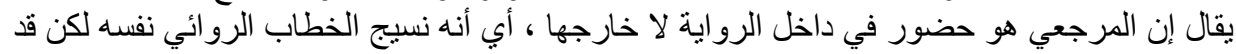

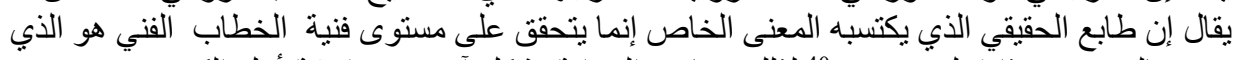

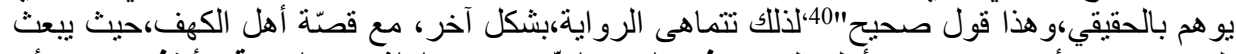

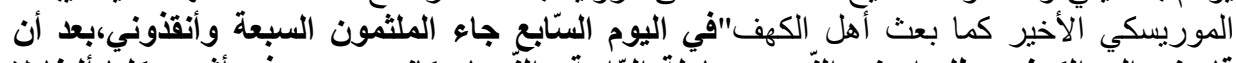

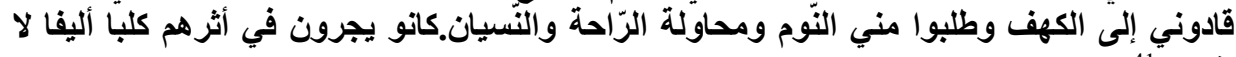

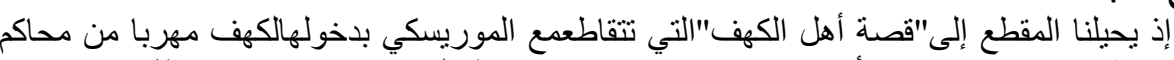

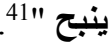

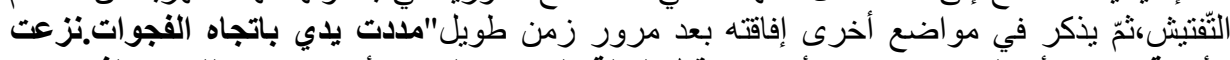

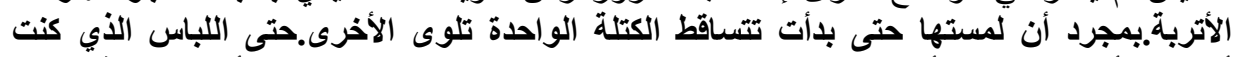

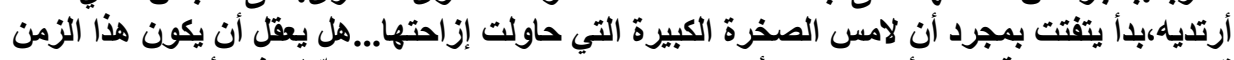

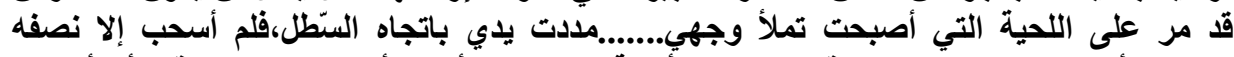

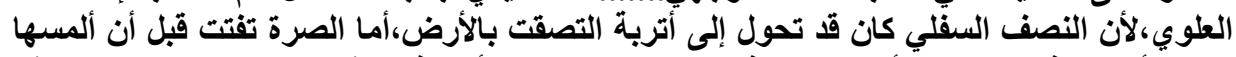

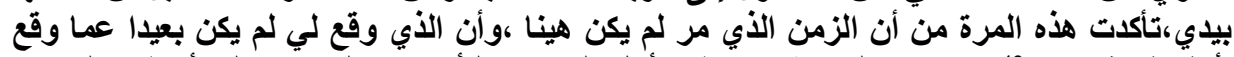

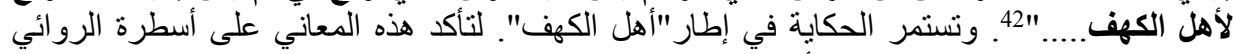

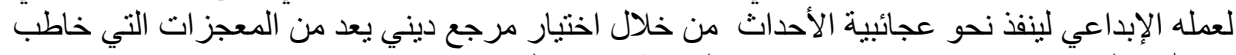

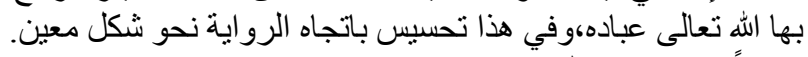

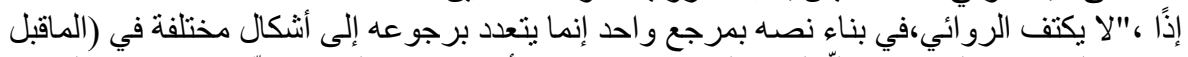

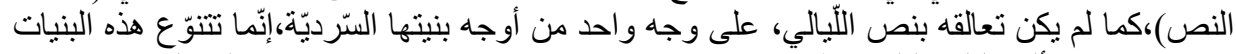

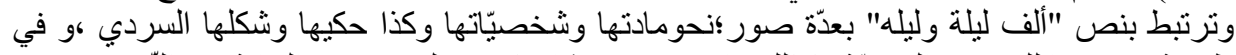
طريقة تضمينها للقصص الفرعيّة وكذللك ما يحدث من تثابه كبير على مستوى البداية بين النّائهين. 3- 2- 2 2بايات الحكاية:

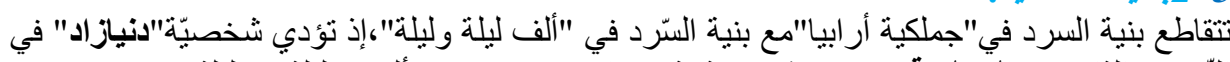

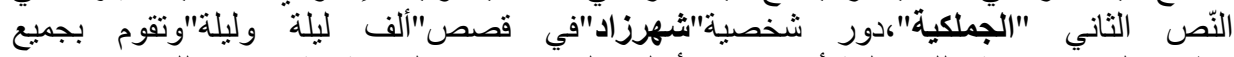
وظائفها:لتكون زوجة ملك مملكة أرابيا في الأندلس(الغرب) مقابلا لزوجة "شهريار"ملك بلاد ساسان 
من جزر الهند و الصين 43(الشرق)،وهي راوية الحكايات في النّص اللاّحق مقابلا لراويتها "شهرزاد"في

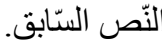

تأدية هذين الثخصيتين لدور الراوي للقصة نفسها في النّصين،جعل النّص الثناني ييدو إعادة للنص لأنص

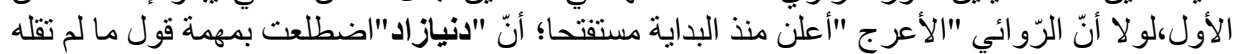

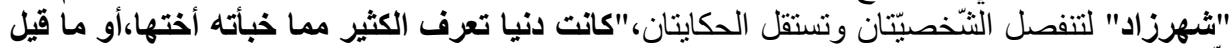

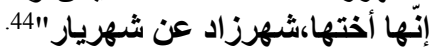

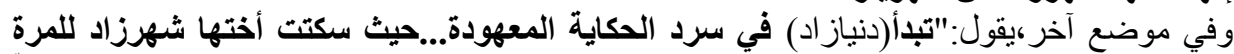

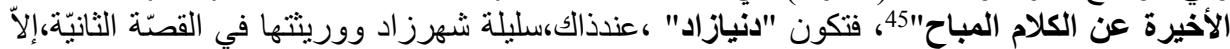
أنّها ستقول مالم تقله أختها،و هو ما تحدّده كل من المدونتين عند التّعريف بهما.

\begin{tabular}{|c|c|c|}
\hline 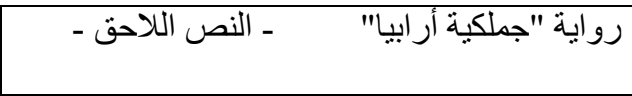 & السابق- " ألف ليلة وليلة" النص & \\
\hline دنياز اد=ر او مصاحب( فاعل داخلي) & شهرزاد = ار او عليم (خارجي) & 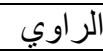 \\
\hline الحاكم بأمره،حاكم مملكة آرابيا & الملك شهريار ،حاكم بلاد ساسان & 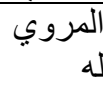 \\
\hline 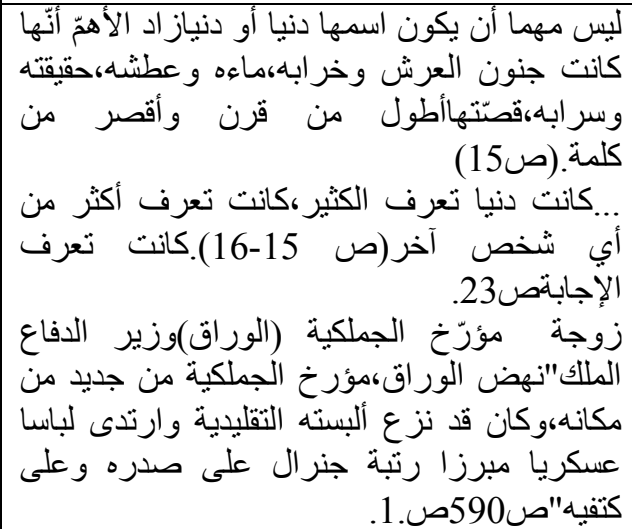 & 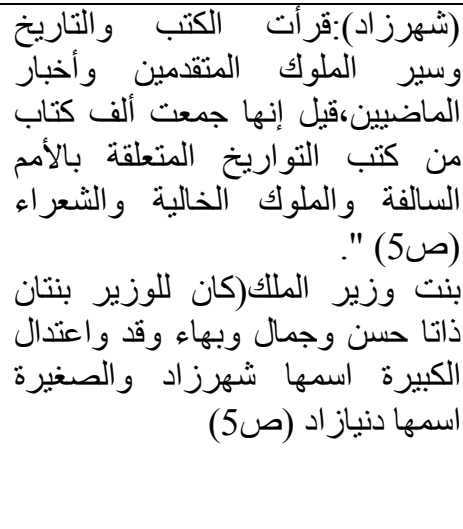 & 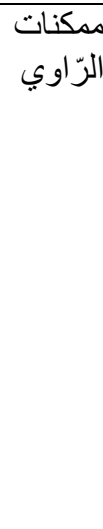 \\
\hline
\end{tabular}

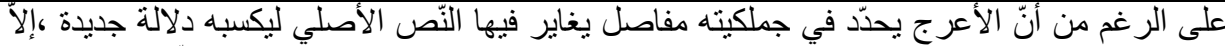

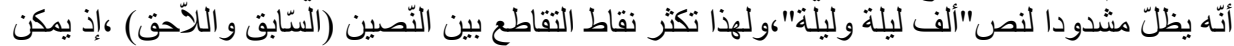

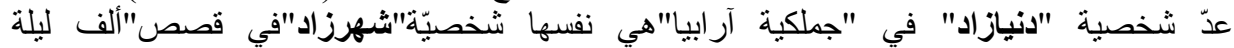

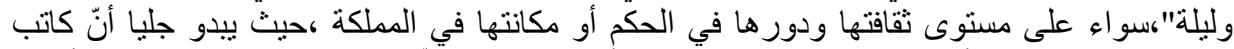

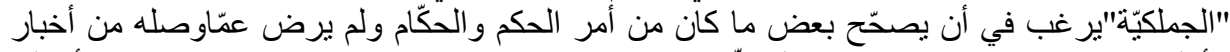

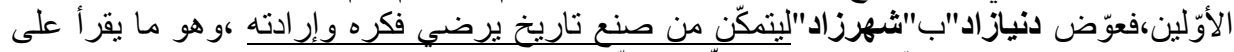

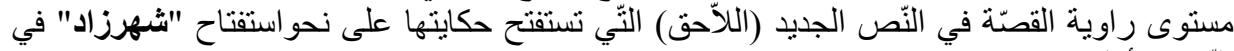

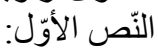




\begin{tabular}{|c|c|}
\hline ألف ليلة وليلة" شهرزاد" في النّص السّابق"قصص & آرابتفاحات دنيا زاد في النص اللاحق "جملكية \\
\hline 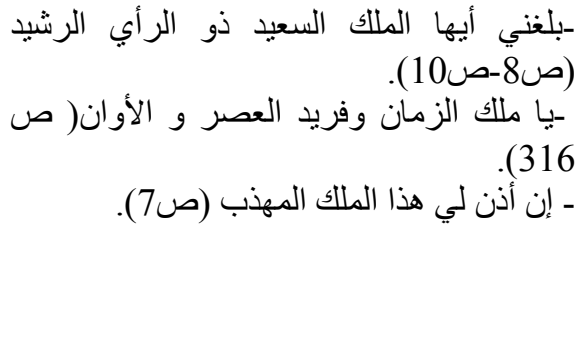 & 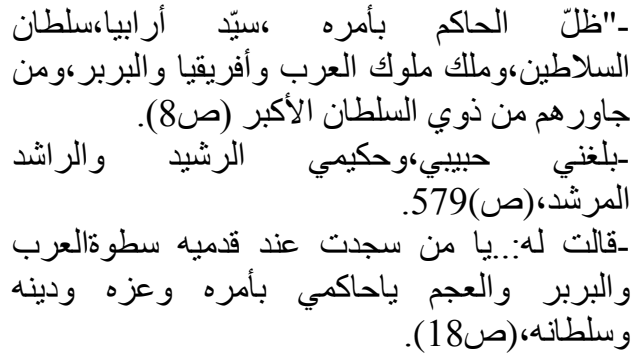 \\
\hline
\end{tabular}

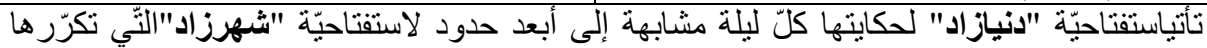

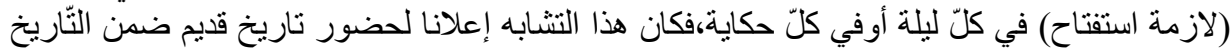

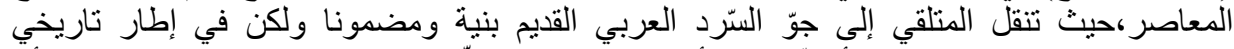

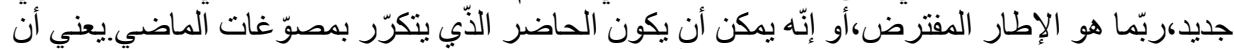

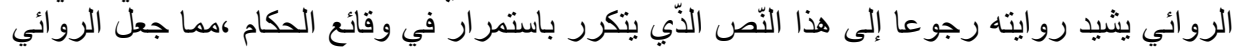

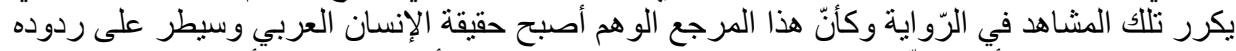

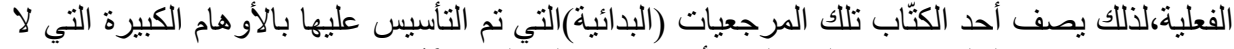

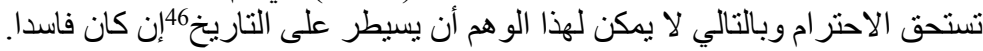

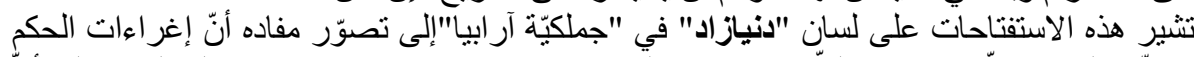

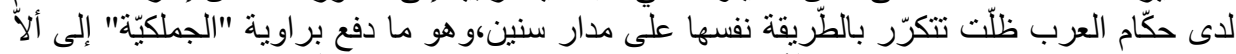

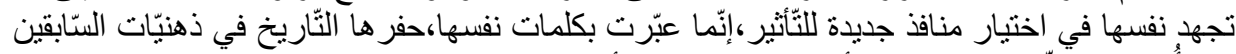

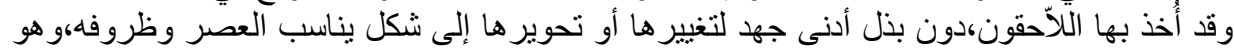

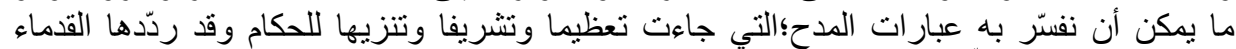

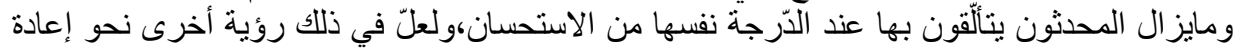

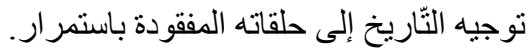

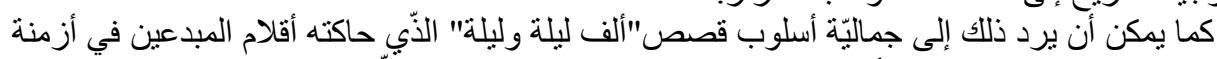

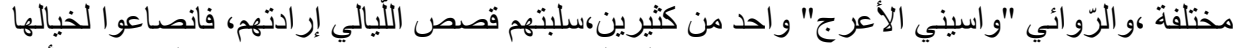

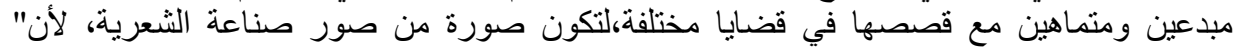

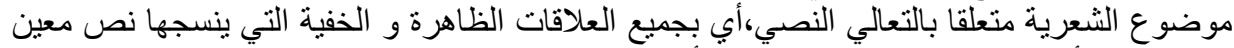

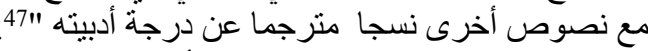

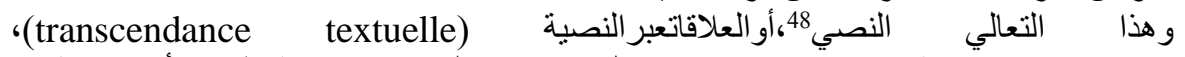

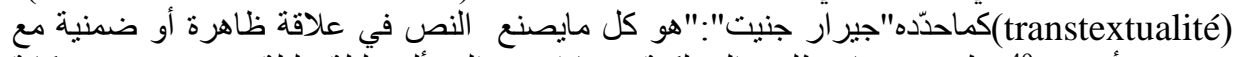

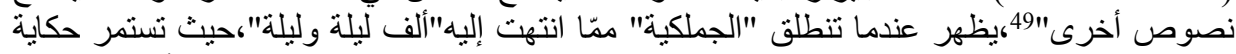

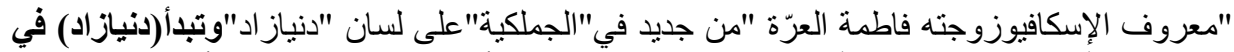

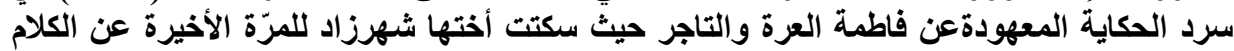

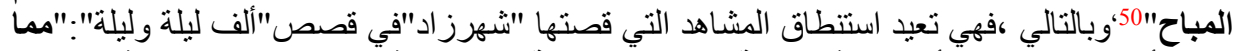

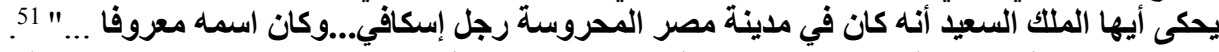

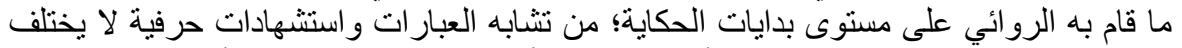

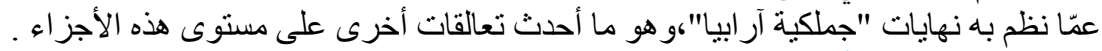




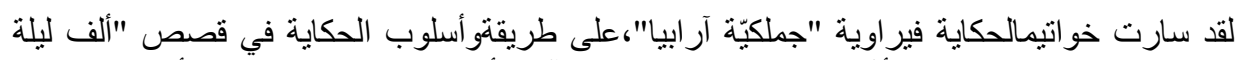

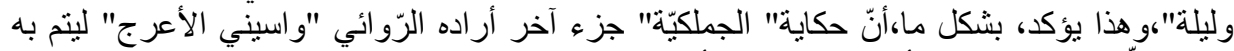

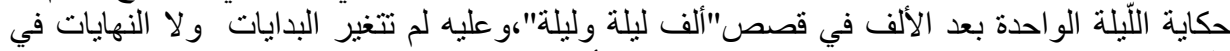

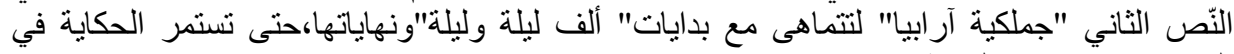

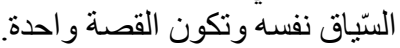

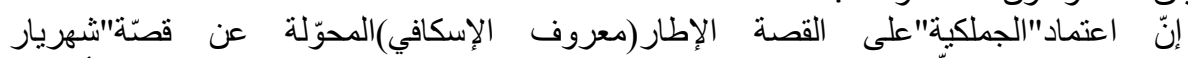

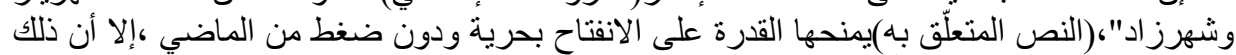

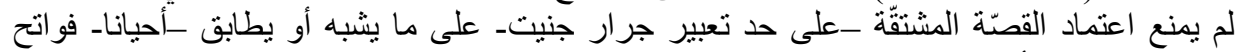

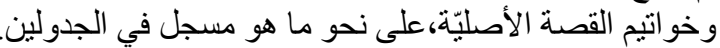

\begin{tabular}{|c|c|}
\hline خو اتيم القصة (ألف ليلة وليلة) & خو اتبم القصة (جملكية آر ابيا) \\
\hline المياحرك شهرز أد الصباح فسكتت عن الكلام & ل أن أصعت عن \\
\hline
\end{tabular}

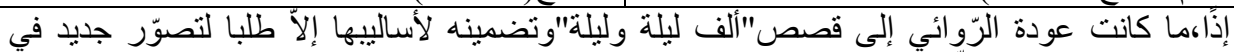

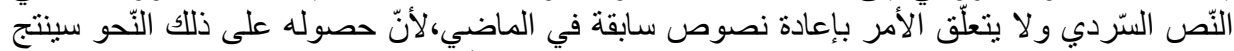

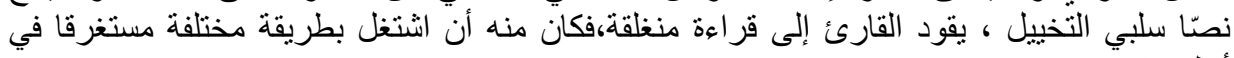

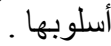

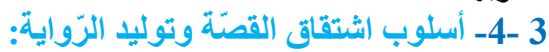

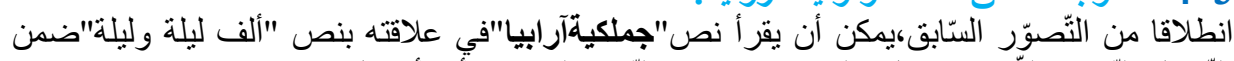

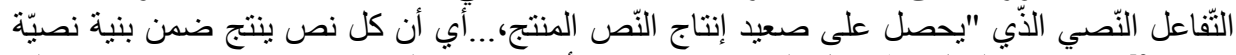

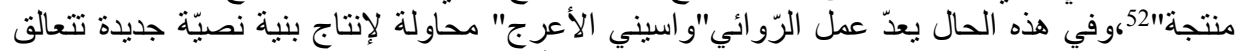

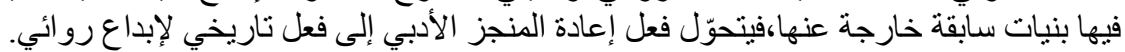

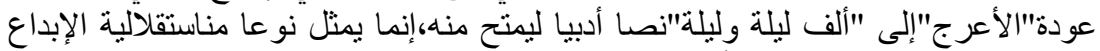

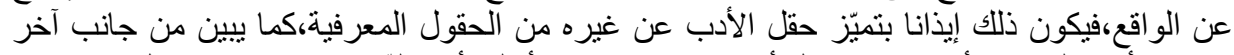

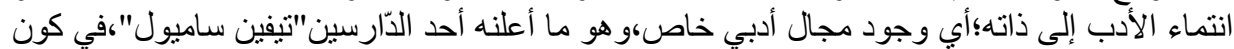

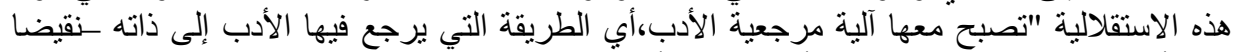

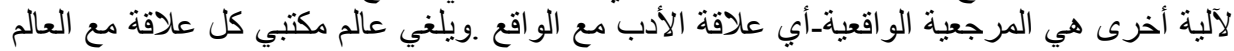

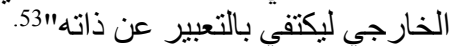

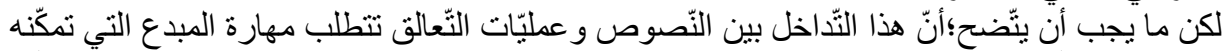

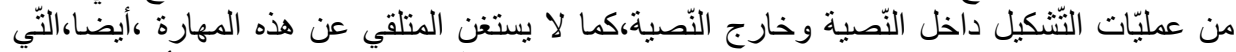

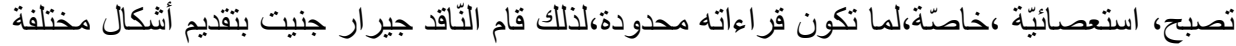

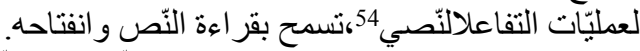

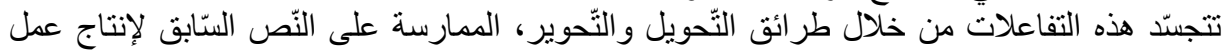

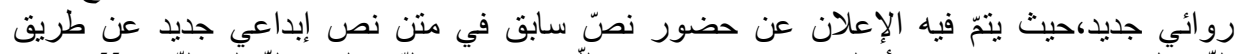

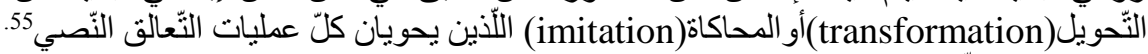

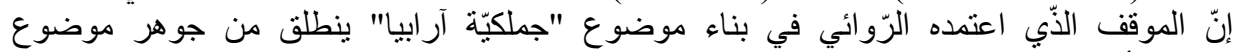

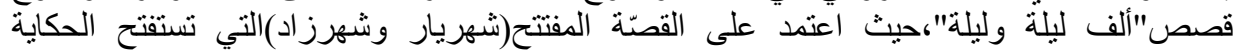

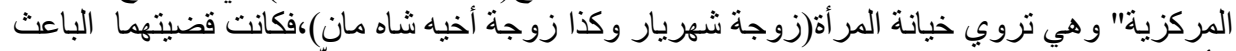

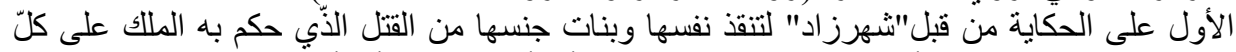

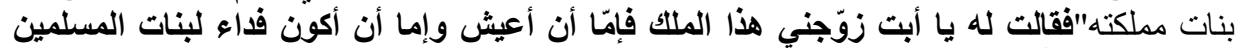

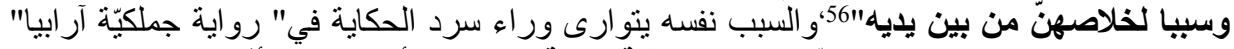

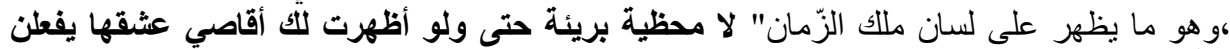

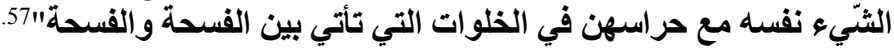




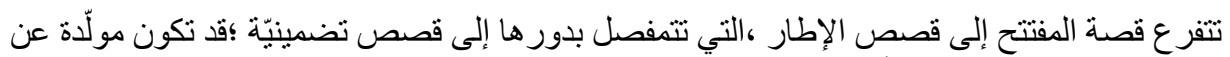

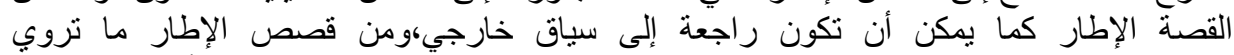

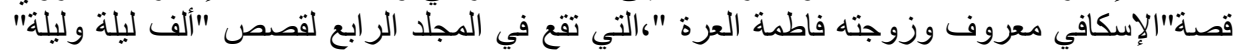

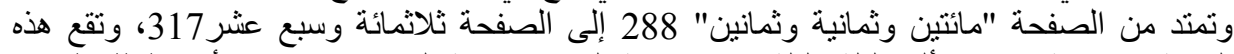

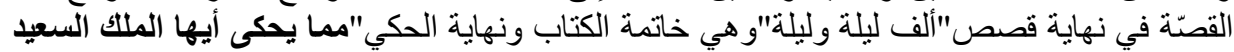

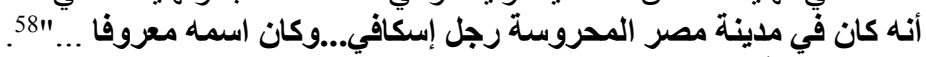

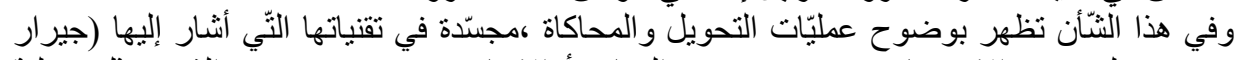

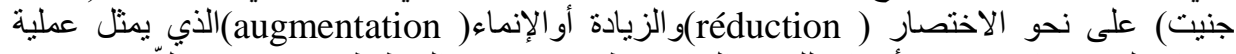

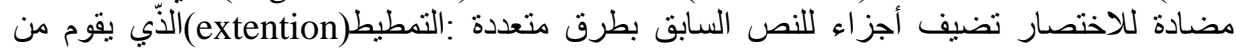

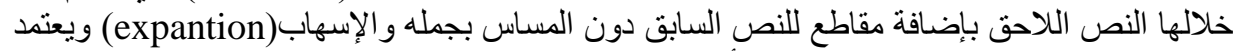

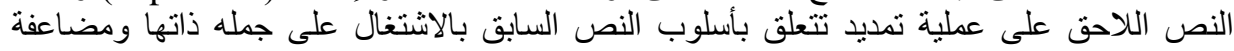

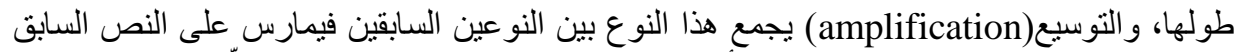

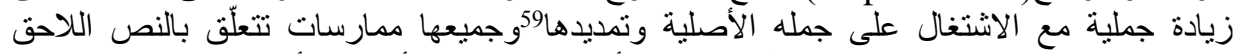

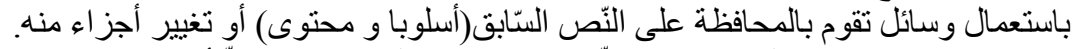

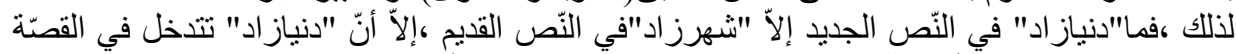

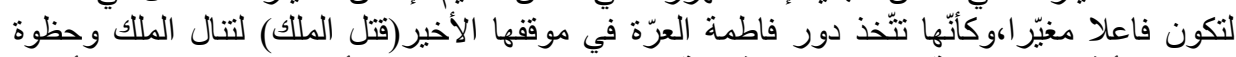

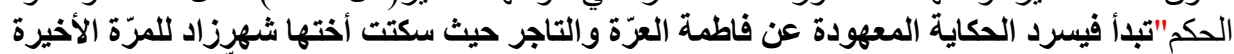

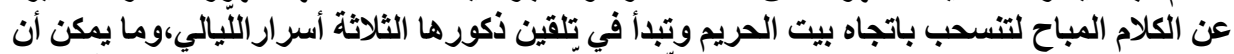

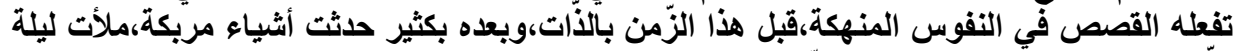

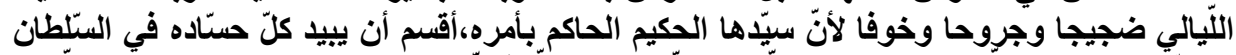

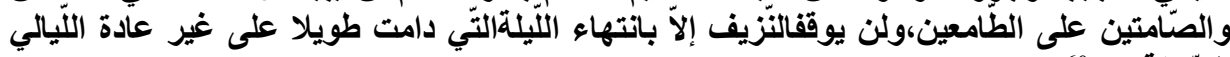

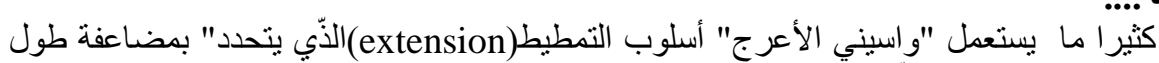

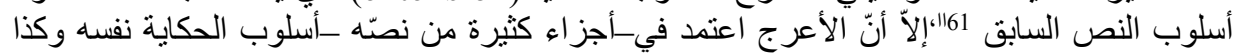

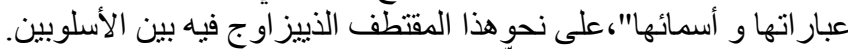

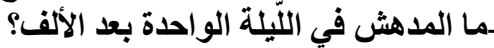

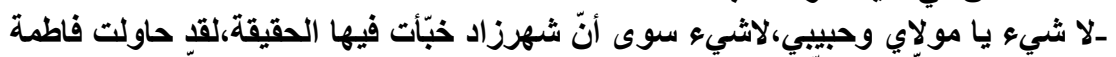

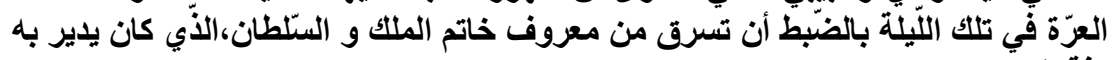

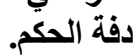

- خائنة،ليس غريبا على النّساء.

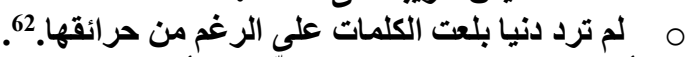

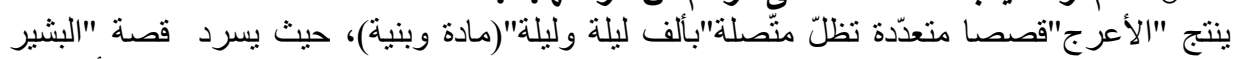

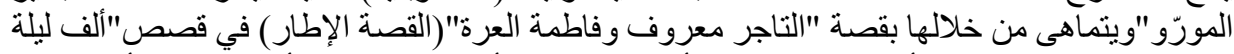

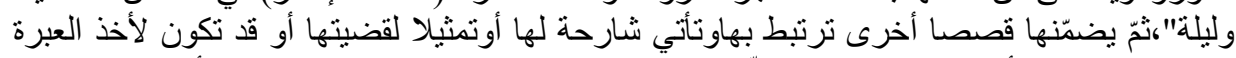

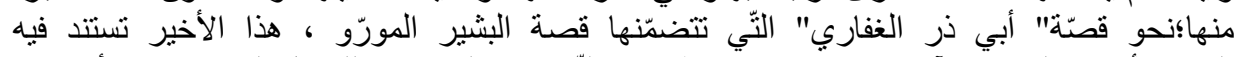

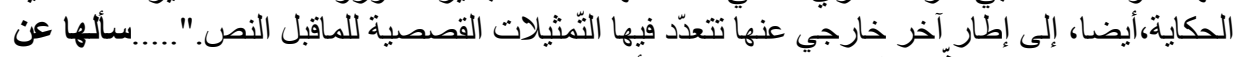

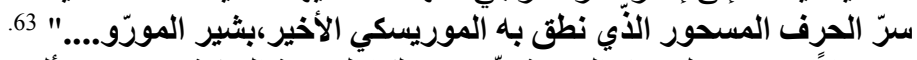

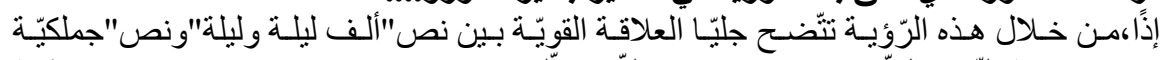

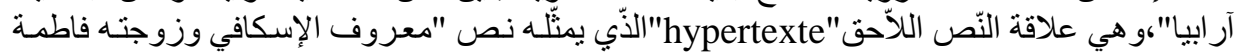

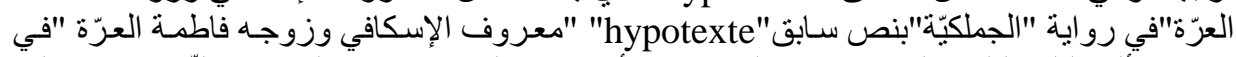

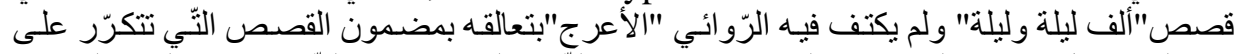

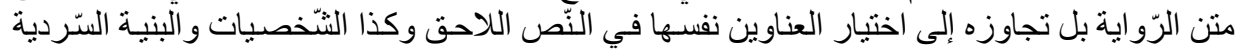


وتقنية الأسلوب،مثل:

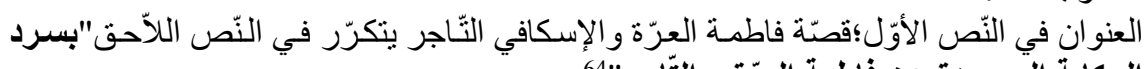

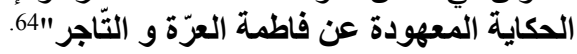

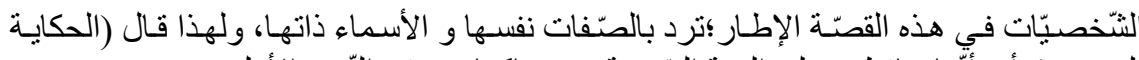

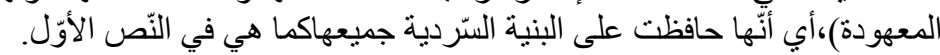

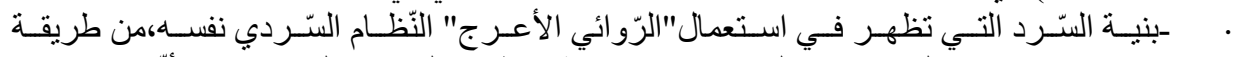

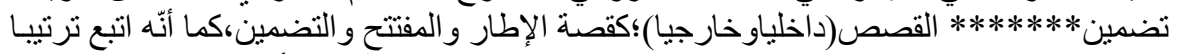

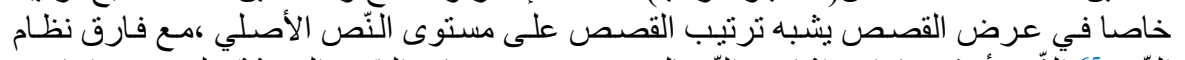

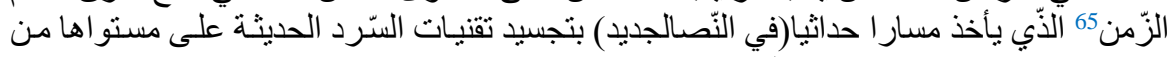

\begin{tabular}{|c|c|c|}
\hline & النّص اللأحق"جملكية آر ابيا" & النّص السابق'ألف ليلة وليلة' \\
\hline 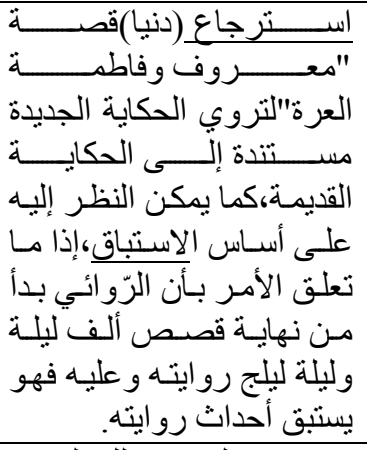 & 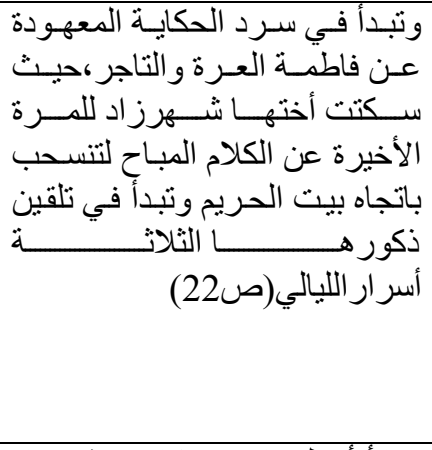 & 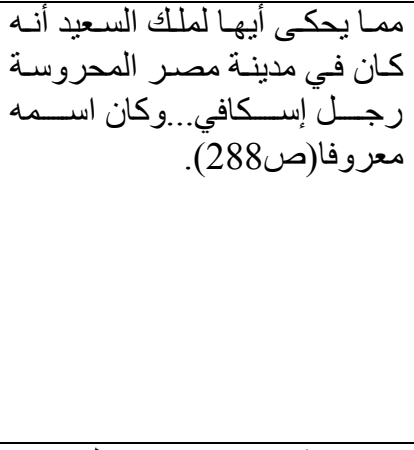 \\
\hline 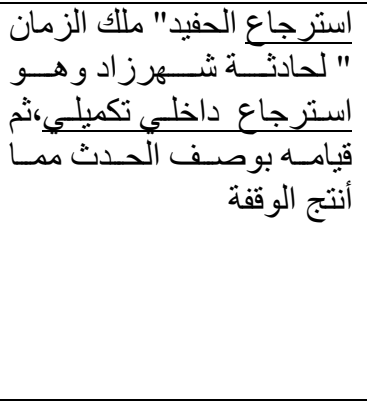 & 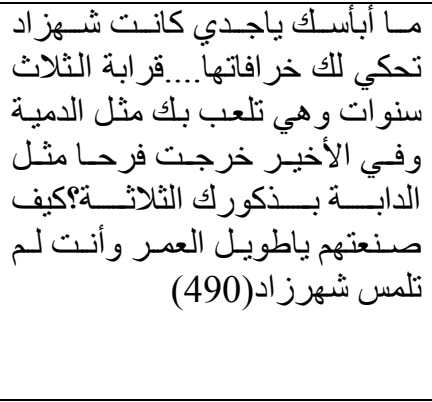 & 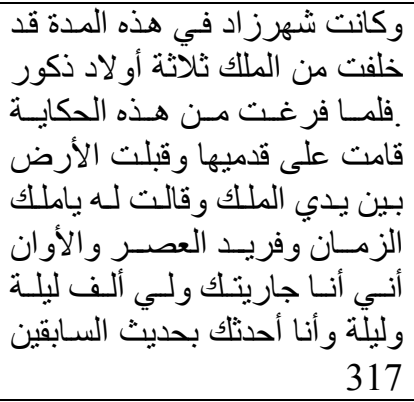 \\
\hline
\end{tabular}




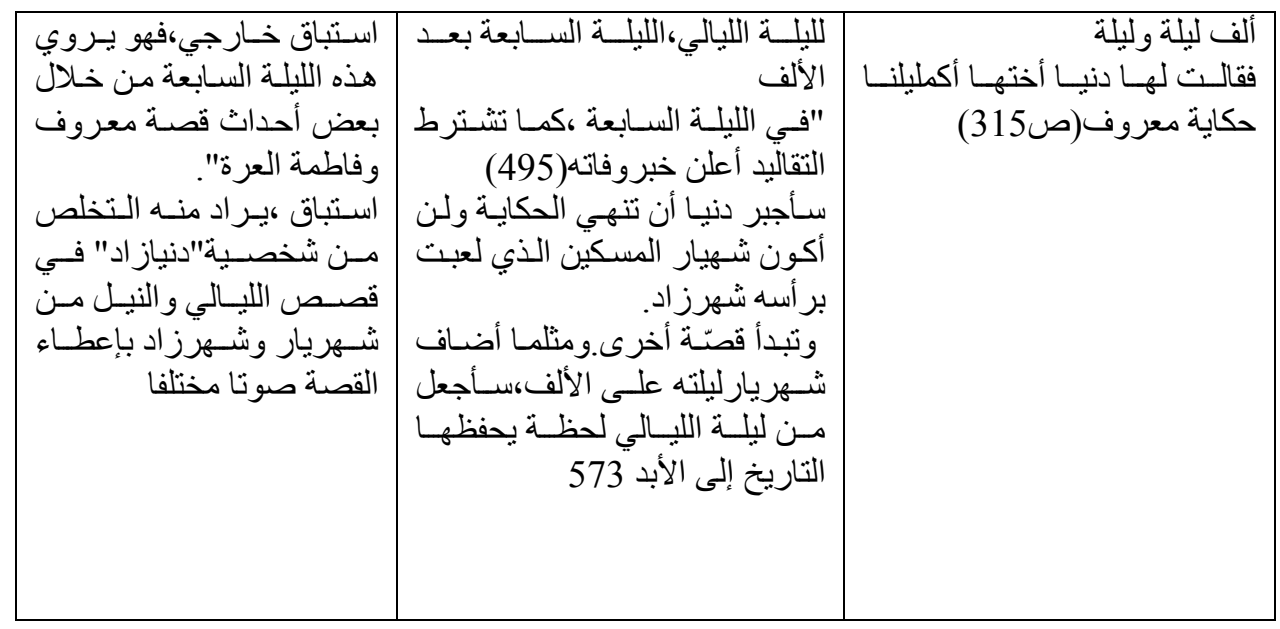

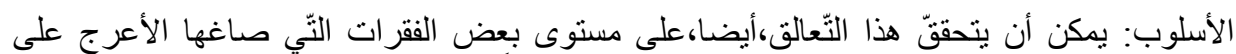

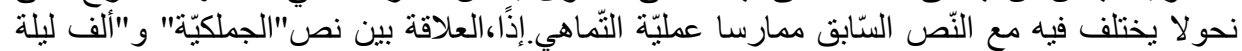

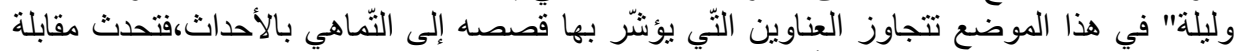

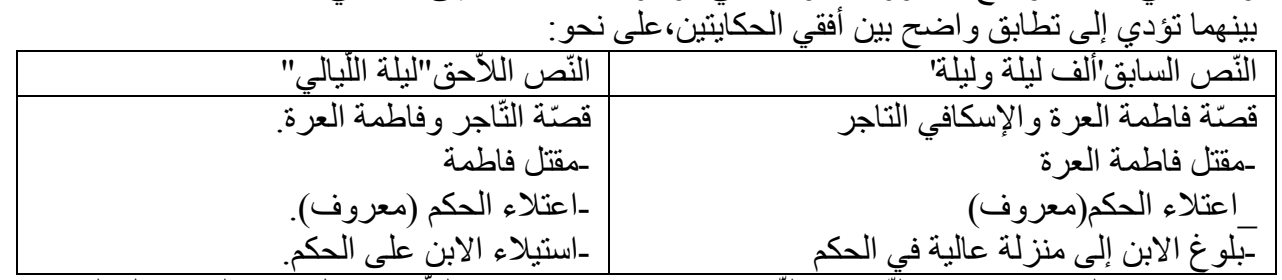

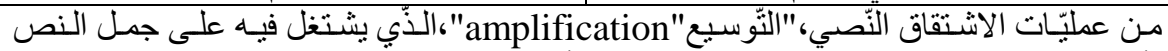

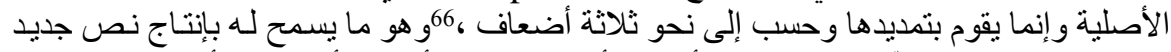

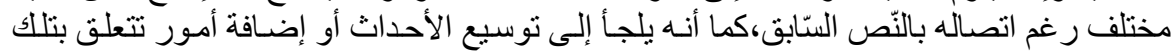

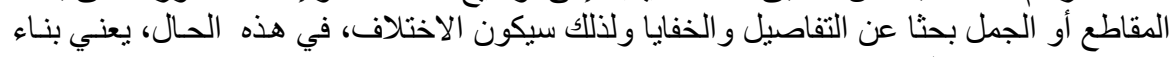

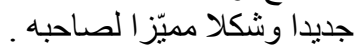

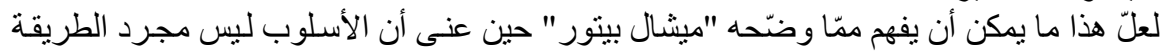

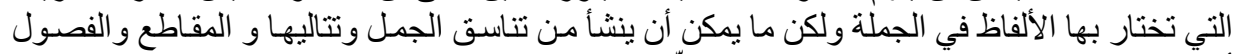

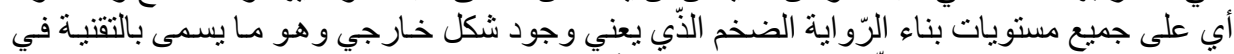

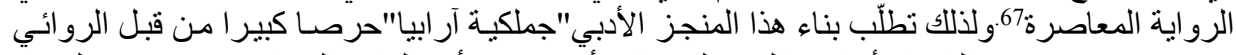

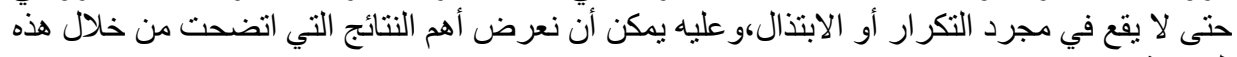

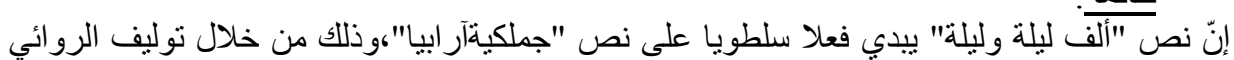

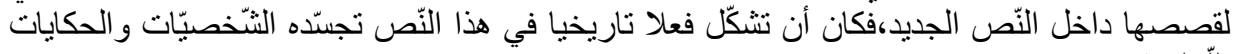

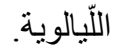

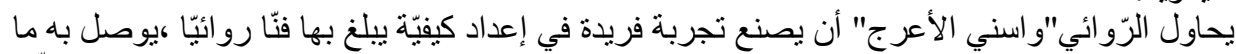

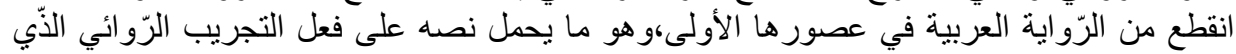

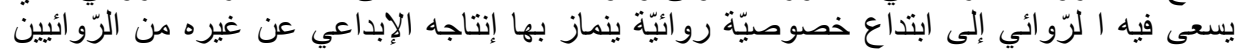


ويؤصّل لتجربة فريدة في الوقت نفسه،وهو ما يدفعه، في كثير من أعماله، إلى تكر ارتيمات نفسها،حيث

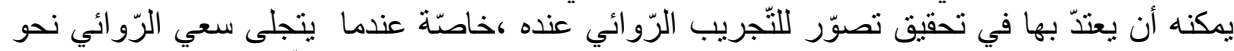

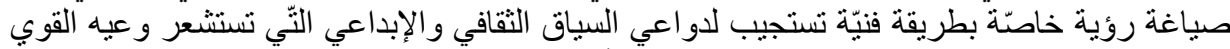

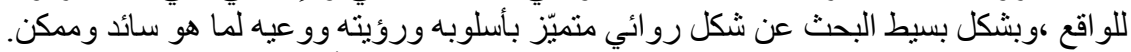

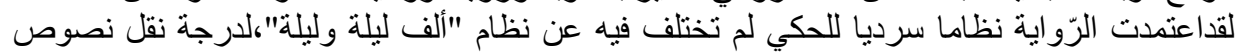

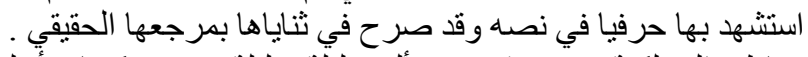

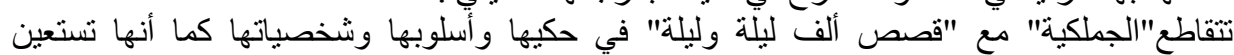

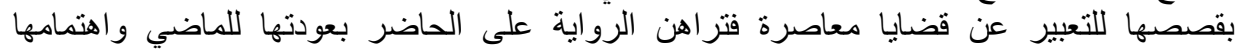

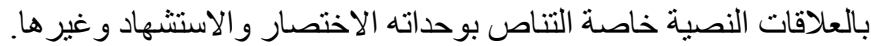

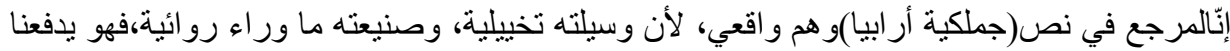

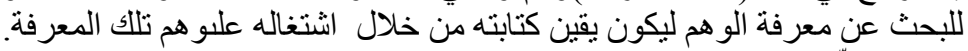

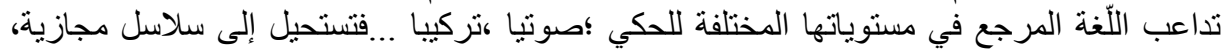

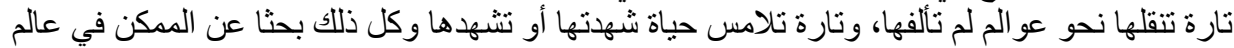

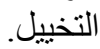
إن العوالم المككنة التخييلية في الرو اية هي عو الم تخييل للحقيقةتارة واللاحقيقة تارة أخرى،لامتلاكها تللك المرجعيّة التّاريخية في الو اقع و المرجعيةٌ التخييلية في الرواية.

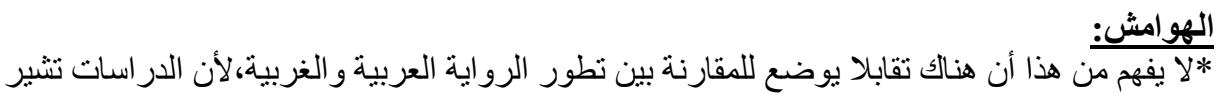

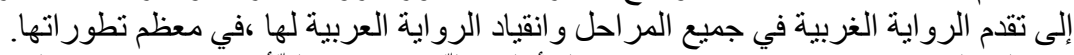

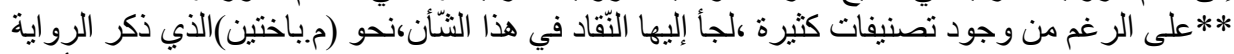

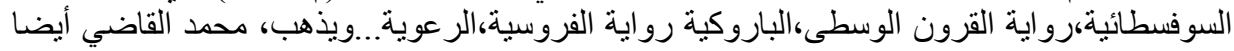

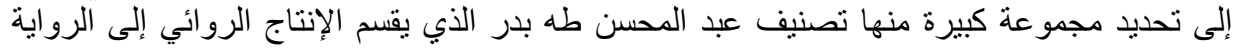

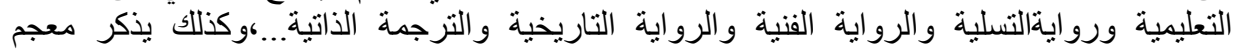

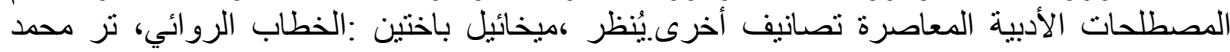

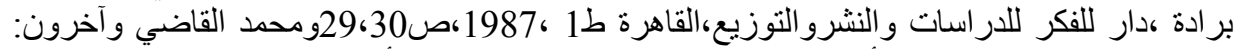

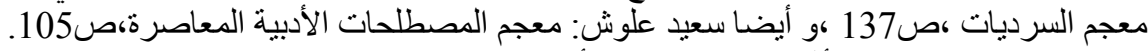

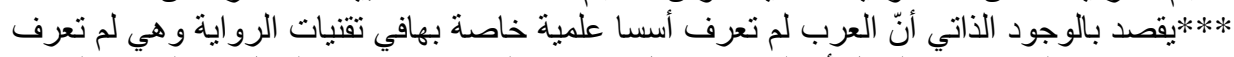

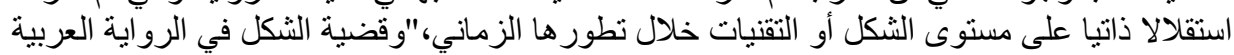

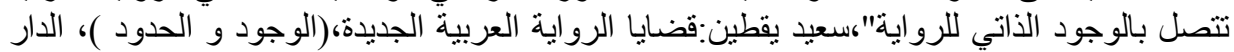

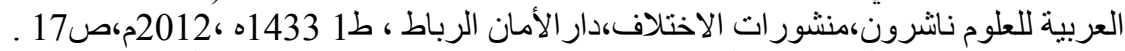

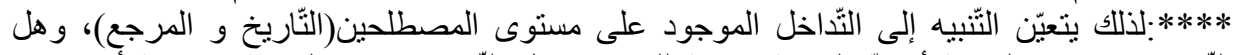

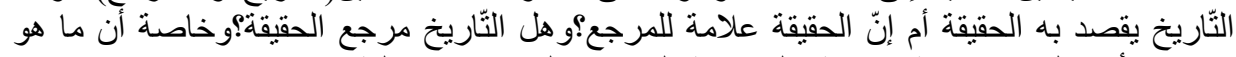

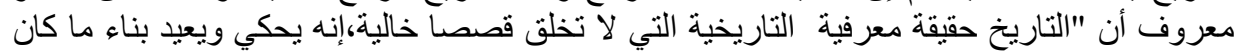

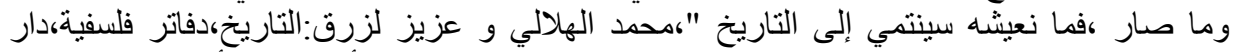

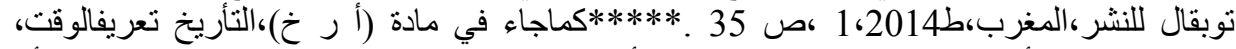

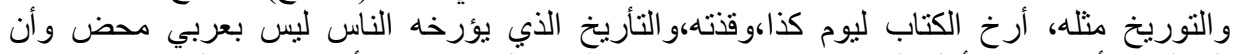

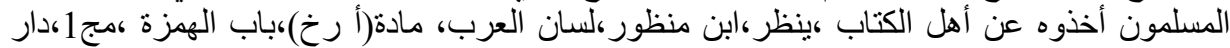

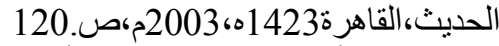

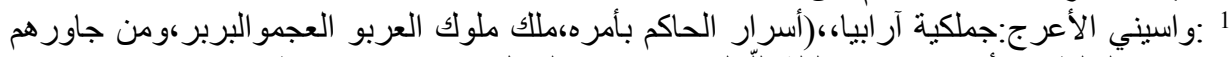
من ذوي السلطان الأكبر)،حكايات ليلة اللّيالي،منشور الئات الجمل،بيروت-بغداد ، ط1 ، 2011. 
2:ينظر،ابن منظور(محمد بن مكرم بن علي أبو الفضل جمال الدين): لسان العرب،مج 4،مادة(ر ج ع

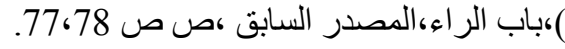

3 : new oxford ,learner's pocket dictionary oxford university press ,ed 4,2011,p369.

4:ينظر ،محمد القاضي و آخرون:معجم السرديات، دار محمد علي للنشر،تونس،دار فر ابي ،لبنان،دار

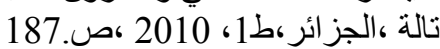

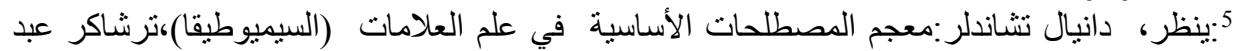

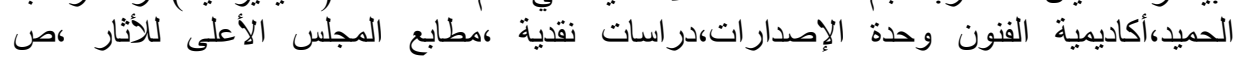

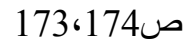
6:ينظر،باتريك شارودو،دومينيك منغنو:معجم تحليل الخطاب، كتر عبد القادر المهيري،حمادي

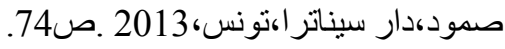

7:jean dubois et autres :le dictionnaire de linguistique et des sciences du langage ,ed la rousse dictionnaires ,paris,2012,p 405.

8: ينظر ،جير الد برنس:المصطلح السردي،تر عابد خزندار،المجلس الأعلى

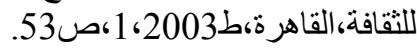
${ }^{9}$ :op-cit ,jean dubois et autres ,p404..

10 :voir , ;A.j.Greimas,j.Courtés :sémiotique,dictionnaire raisonné de la théorie du langage,tome 1 ,ed hachette universite,paris ,1979,p p310,311 .

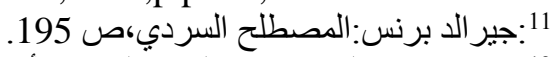

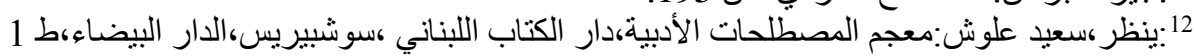

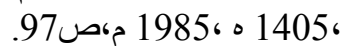
13: تزفيطان تودوروف:مفاهيم سردية،تر عبد الرحمان مزيان،منشور ات الاختلاف ط2005، 1،ص ص ${ }^{14}$.le grand la rousse ,ed la rousse ,2014,pp 494،595.6 15 : ينظر،مفتاح محد وبوحسن أحمد:المفاهيم وأشكال التواصل،منشورات كلية الآداب والعلوم

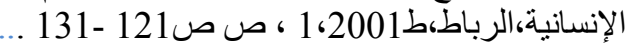

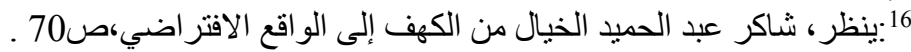

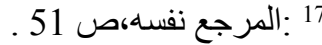
18

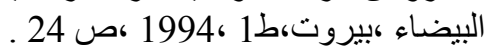

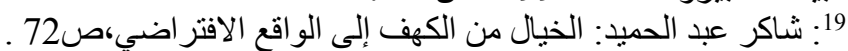

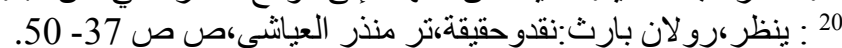
21:داود سلبمان الثويلي:ألف ليلة وليلة وسحر السردية العربية (دراسات)منشور ات ات اتحاد كتاب

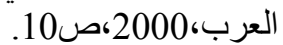

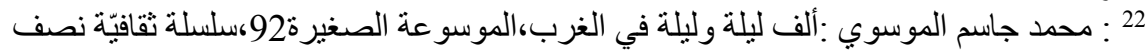

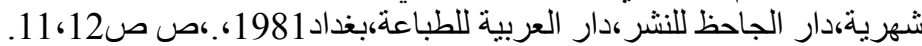

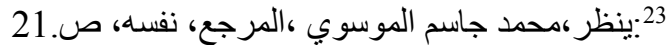

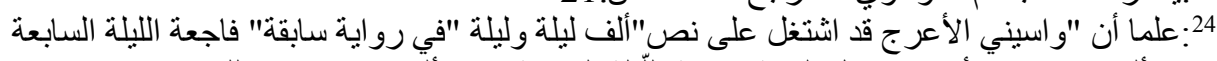

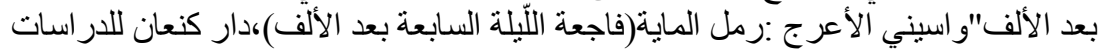

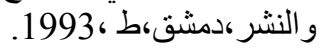




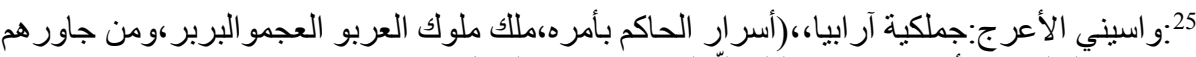

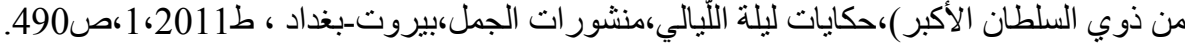

26 : سعيد بنكر اد : السيميائيات السردية دار الدوار للنشر و التوزيع ، ط1 ، 2012 ، ص161 . 27 : 26

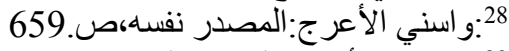

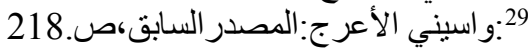
30 :تزفيتان تودوروف:ميخائيل باختين،تر فخري صالح،رؤية للنشرو التوزيع،القاهرة ،ط1 ،2012،ص

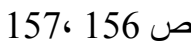

31 :julia kristeva :le texte du roman ,approche sémiologique d'une structure discursive transformationnelle , mouton publishers ,paris,new york,ed3 ,1979 ,p12

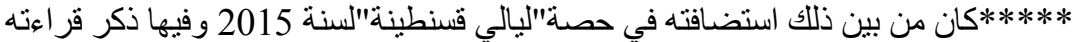

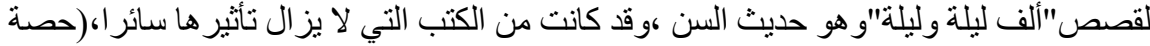

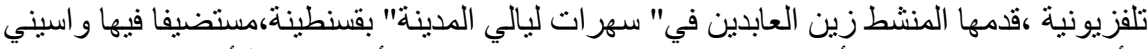

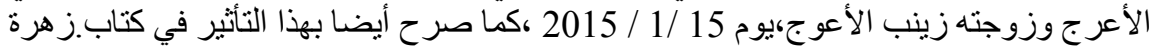

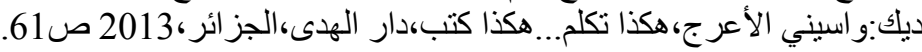
$:{ }^{32}$ Gérard Genette ,palimpsestes,(la littérature au second degré ),éd seuil ,1982,p16.

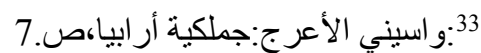
34: 3يظر،ميشال بيتور:بحوث في في الرواية الجديدة،تر، فريدأنطونيوس،منشور رات عويدات بيروت،باريس

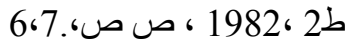

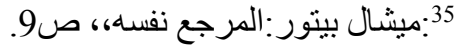
20 37 :,tzvetan todorov :introduction à littérature fantastiqueTodorov,éd du seuil,1970,p65 .

******: voir, tzvetan todorov :ibid ,pp60-62

$$
\text { 39: 38 المصدر السابق ،ص111. }
$$

40: يمنى عيد : فن الرواية العربية بين خصوصية الحكاية وتميز الخطاب، دار الاداب ط 1، 1998 .26.

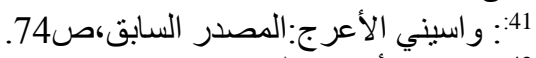

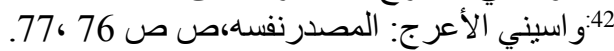
43:ينظر، 4جهولة المؤلف: ألف ليلة وليلة، التز ام سعيد علي الخيلة الخصوصي، ،مقابلة ومصححة على النسخة

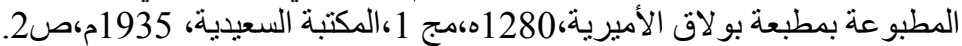

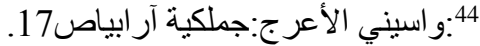

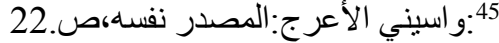

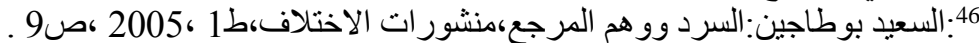

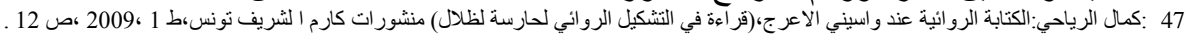

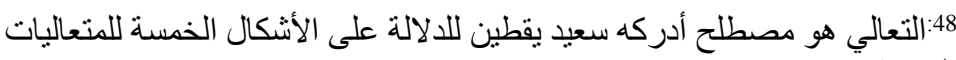
transcendance textuelle. النصية النعالئ 
معمارية النص ،المناصة ،التناص ،الميتانصية،التعلق النصي،ينظر سعيد يقطين:الرواية و التراث

${ }^{49}$ :Gerard genette,palimpsestes ,p7.

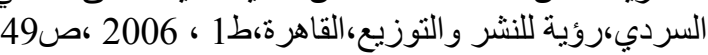

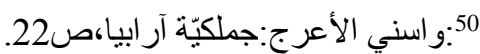

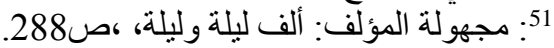

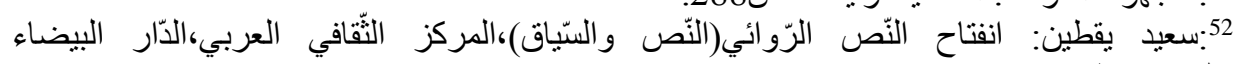

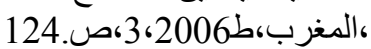

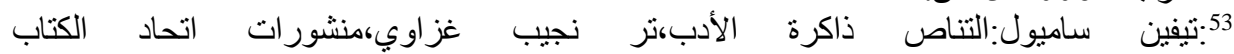
2 العربي،دمشق، 54: لا يختلف التفاعل النصي عن المتعاليات النصية،لأن التفاعل ينحقق بحسب هيمنة أحد أنواع

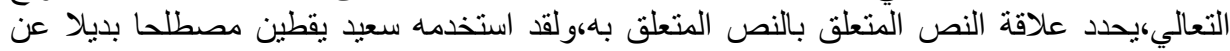

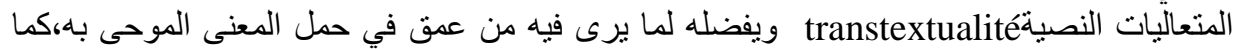

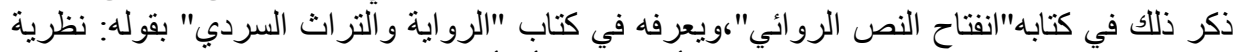

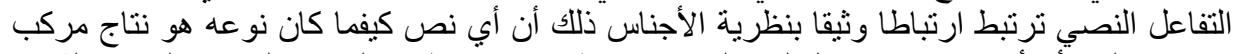

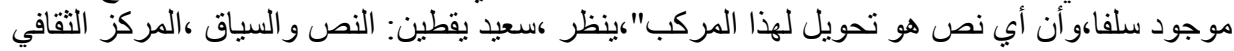

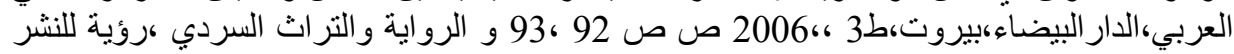

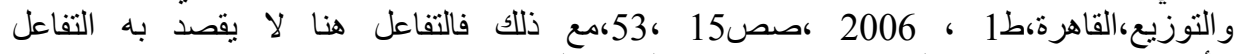

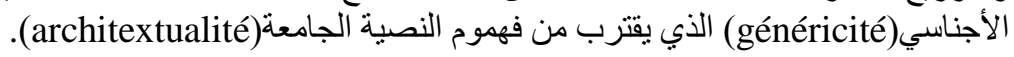
${ }^{55}$ :voir,Gérard Genette ,palimpsestes, p15.

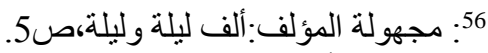

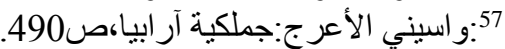

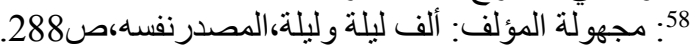

${ }^{59}$ :voir,Gérard Genette ,palimpsestes,pp 364-,377.

${ }^{61}$ :Gérard Genette ,op-cit ,p364

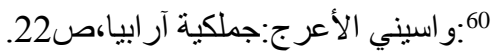

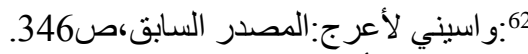

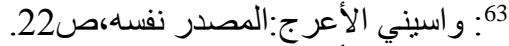

$$
\begin{aligned}
& \text { 646: واسيني الأعرج:المصدر نفسه ،صن ن. }
\end{aligned}
$$

${ }^{65}$ :Gérard Genette ,palimpsestes,p372

.

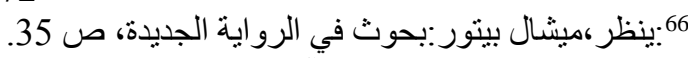

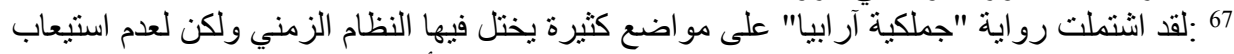

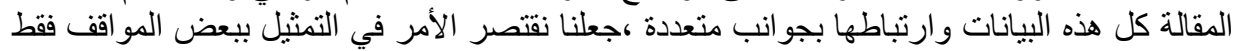

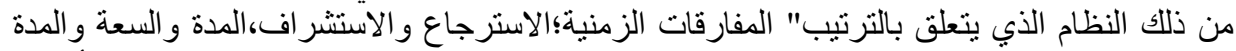

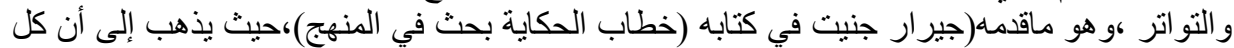

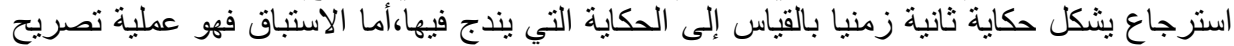

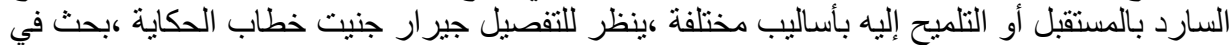

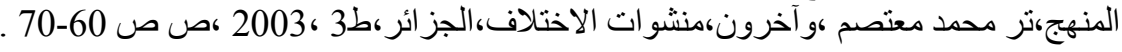


قائمة المصادر و المراجع:

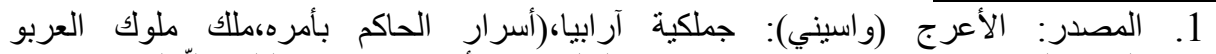

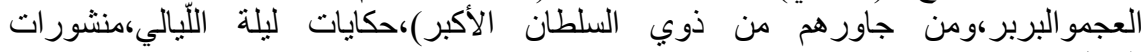

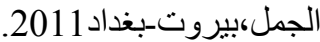

2. الرجإياحي (كمال):الكتابة الروائية عند واسيني الاعرج)(قراءة في التشكيل الروائي لحارسة

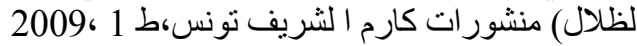

3. الشويلي( داود سليمان):ألف ليلة وليلة وسحر السردية العربية (دراسات)منشورات اتحاد كتاب

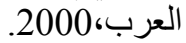

4. القاضي( محمد) ومجموعة مؤلفين:معجم السرديات،دار محمد علي للنشر،تونس،دار فرابي

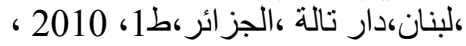

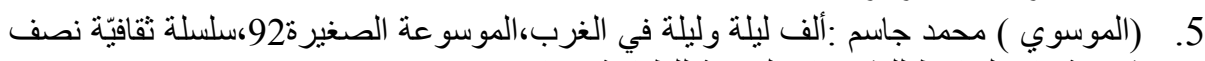

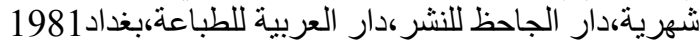

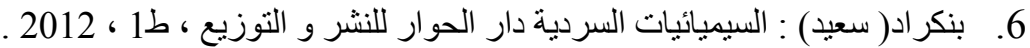
7.

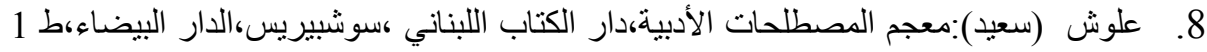
1985، 1405،

9. عيد (يمنى ): فن الرواية العربية بين خصوصية الحكاية وتميز الخطاب، دار الاداب ط 14، 1998

10. مجهولة المؤلف: ألف ليلة وليلة،التزام سعيد علي الخصوصي، ،مقابلة ومصححة على النسخة المطبو عة بمطبعة بو لاق الأميرية، 1280هـهمج 128 1، المكتية المكتبة السعيدية، 1935

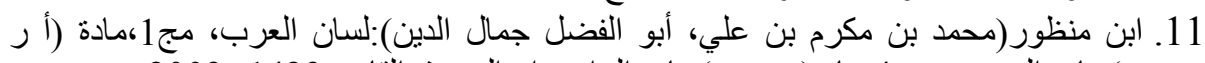

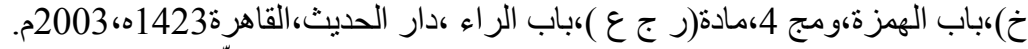

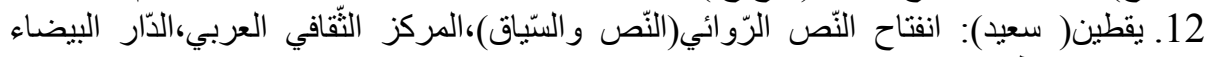
كبيروت،ط 3 ، 3 ،

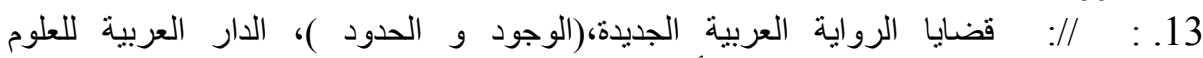

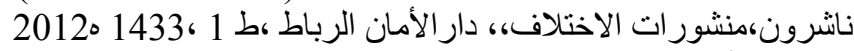

المر اجع المترجمة

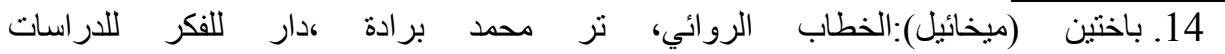

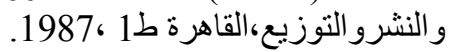

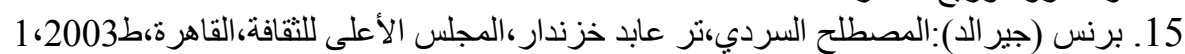

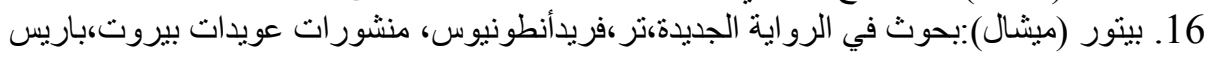

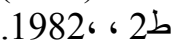

17. ـتشاندلر ( دانيال):معجم المصطلحات الأساسية في علم العلامات،ر شاكر عبد الحميد،أكاديمية الفنون وحدة الإدار ات دران دوراسات نقدية.

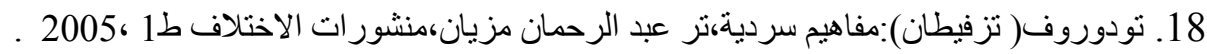

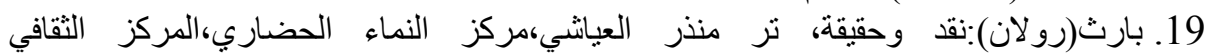

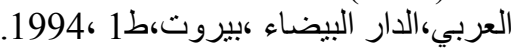

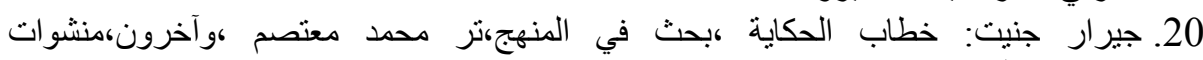
الاختلاف، الجز ائر،ط3 ، 2003 2. 


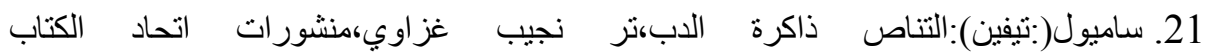

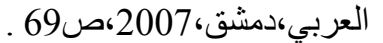

22. شارودو (باتريك) ، منغنو (دومينيك) :معجم تحليل الخطابهتر عبد القادر المهيري،حمادي

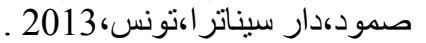
23. كونديرا (ميلان):فن الرواية،تربدر الدين عرودكي،أفريقيا الثرق، المغرب، 2001. المراجع الأحنبية: الميرن

. ${ }^{24}$ :A.j.Greimas,j.courtés :sémiotique,dictionnaire raisonné de la théorie du langage,tome 1 ,ed hachette universite ,paris, 1979.

25 :Jean dubois et autres :le dictionnaire de linguistique et des sciences du langage ,ed la rousse dictionnaires ,paris, 2012.

26 :Gérard Genette ,palimpsestes,(la littérature au second degré ),ed seuil ,1982.

27 :Julia kristeva :le texte du roman ,approche sémiologique d'une structure discursive transformationnelle ,mouton publishers ,paris,new york,ed3,1979

28 :New oxford, learner's pocket dictionary oxford university press ,ed 4,2011.

29 :Tzvetan Todorov :introduction à littérature fantastiqueTodorov ,éd du seuil,1970 